\title{
Phylogenomics of Plant-Associated Botryosphaeriaceae Species
}

\section{Jadran F. Garcia', Daniel P. Lawrence ${ }^{2}$, Abraham Morales-Cruz ${ }^{1,3}$, Renaud Travadon², Andrea Minio', Rufina Hernandez-Martinez ${ }^{4}$, Philippe E. Rolshausen ${ }^{5}$, Kendra Baumgartner ${ }^{6}$ and Dario Cantu ${ }^{1 *}$}

\begin{abstract}
1 Department of Viticulture and Enology, University of California, Davis, Davis, CA, United States, ${ }^{2}$ Department of Plant Pathology, University of California, Davis, Davis, CA, United States, ${ }^{3}$ Department of Ecology and Evolutionary Biology, University of California, Irvine, Irvine, CA, United States, ${ }^{4}$ Centro de Investigación Científica y de Educación Superior de Ensenada, Ensenada, Mexico, ${ }^{5}$ Department of Botany and Plant Sciences, University of California, Riverside, Riverside, CA, United States, ${ }^{6}$ Crops Pathology and Genetics Research Unit, United States Department of Agriculture - Agricultural Research Service, Davis, CA, United States
\end{abstract}

\section{OPEN ACCESS}

Edited by:

Chia-Lin Chung,

National Taiwan University, Taiwan

Reviewed by:

David Gramaje,

Institute of Vine and Wine Sciences

(ICWV), Spain

K. W. Thilini Chethana,

Mae Fah Luang University, Thailand

*Correspondence:

Dario Cantu

dacantu@ucdavis.edu

Specialty section

This article was submitted to Microbe and Virus Interactions with

Plants,

a section of the journal

Frontiers in Microbiology

Received: 13 January 2021

Accepted: 25 February 2021

Published: 18 March 2021

Citation:

Garcia JF, Lawrence DP Morales-Cruz A, Travadon $R$, Minio A, Hernandez-Martinez $R$

Rolshausen PE, Baumgartner $K$ and Cantu D (2021) Phylogenomics of Plant-Associated

Botryosphaeriaceae Species.

Front. Microbiol. 12:652802. doi: 10.3389/fmicb.2021.652802
The Botryosphaeriaceae is a fungal family that includes many destructive vascular pathogens of woody plants (e.g., Botryosphaeria dieback of grape, Panicle blight of pistachio). Species in the genera Botryosphaeria, Diplodia, Dothiorella, Lasiodiplodia, Neofusicoccum, and Neoscytalidium attack a range of horticultural crops, but they vary in virulence and their abilities to infect their hosts via different infection courts (flowers, green shoots, woody twigs). Isolates of seventeen species, originating from symptomatic apricot, grape, pistachio, and walnut were tested for pathogenicity on grapevine wood after 4 months of incubation in potted plants in the greenhouse. Results revealed significant variation in virulence in terms of the length of the internal wood lesions caused by these seventeen species. Phylogenomic comparisons of the seventeen species of wood-colonizing fungi revealed clade-specific expansion of gene families representing putative virulence factors involved in toxin production and mobilization, wood degradation, and nutrient uptake. Statistical analyses of the evolution of the size of gene families revealed expansions of secondary metabolism and transporter gene families in Lasiodiplodia and of secreted cell wall degrading enzymes (CAZymes) in Botryosphaeria and Neofusicoccum genomes. In contrast, Diplodia, Dothiorella, and Neoscytalidium generally showed a contraction in the number of members of these gene families. Overall, species with expansions of gene families, such as secreted CAZymes, secondary metabolism, and transporters, were the most virulent (i.e., were associated with the largest lesions), based on our pathogenicity tests and published reports. This study represents the first comparative phylogenomic investigation into the evolution of possible virulence factors from diverse, cosmopolitan members of the Botryosphaeriaceae.

Keywords: grapevine trunk diseases, Botryosphaeria dieback, comparative genomics, gene family evolution, virulence factors, secondary metabolism, cell wall degrading enzymes 


\section{INTRODUCTION}

The fungal family Botryosphaeriaceae (Botryosphaeriales, Dothideomycetes) was introduced in 1918 by Theissen and Sydow (1918) with Botryosphaeria as the type genus. Members of this group have been taxonomically characterized based on the production of large, ovoid to oblong, typically hyaline, aseptate ascospores, which may become brown and septate with age, within bitunicate asci within unilocular or multilocular botryose ascomata known as pseudothecia (Sivanesan, 1984; Phillips et al., 2005). The asexual states of Botryosphaeriaceae exhibit a wide range of conidial morphologies that are taxonomically informative (Phillips et al., 2005). Crous et al. (2006) contributed to stabilize the taxonomy of the genera within the Botryosphaeriaceae by employing a natural unit classification scheme, which is also referred to as the "genusfor-genus concept" (Seifert et al., 2000). The distinct asexual morphs were linked to unique sexual morphs on a unit-by-unit basis, which was corroborated with phylogenetic analysis of $28 \mathrm{~S}$ rDNA sequence data revealing 10 generic clades. The Botryosphaeriaceae is currently composed of 24 well-defined genera and more than 200 species (Burgess et al., 2019) that are cosmopolitan in distribution and exist primarily as saprobes, endophytes, or pathogens on a wide array of important perennial plant hosts (Slippers and Wingfield, 2007), in both humanaltered (agricultural and urban) and natural ecosystems (forests and riparian areas) (Slippers et al., 2009; Lawrence et al., 2017).

The ecology of Botryosphaeriaceous taxa is complex and not fully understood. For example, in spite of being a shoot blight and canker pathogen of pine, Diplodia sapinea has been isolated from the bark surface and internal woody tissues of woody twigs from asymptomatic Pinus (Petrini and Fisher, 1988), representing what some may consider an "endophytic phase," in which neither the internal plant tissues from which it is isolated, nor other plant tissues/organs showed apparent symptoms, nor were there negative impacts to host growth at the time of isolation. A similar pattern in the ecology of other Botryosphaeriaceae species considered pathogenic, but later being isolated during an endophytic phase, has been documented (Slippers and Wingfield, 2007; Luo et al., 2019; Hrycan et al., 2020). In some cases, abiotic stress (water stress, heat stress) has been shown to induce severe symptoms in different host plants infected with seemingly innocuous Botryosphaeriaceae (Pusey, 1989; Mullen et al., 1991; Smith et al., 1994). This relationship between abiotic stress and more severe symptoms or more rapid colonization has also been reported for pathogenic species, e.g., Neofusiococcum parvum causing Botryosphaeria dieback of grape (Luque et al., 2010; Galarneau et al., 2019) and Botryosphaeria dothidea causing Pistachio panicle and shoot blight (Ma et al., 2001). Under climate-change scenarios of more frequent temperature extremes and prolonged drought, the interactions between host plants and Botryosphaeriaceae species may transit more readily from endophytic to pathogenic (Desprez-Loustau et al., 2006; Slippers et al., 2007). An increase in Botryosphaeriaceae symptom severity in conjunction with other biotic stresses has also been documented in the literature (Old et al., 1990; Lawrence et al., 2018).
Members of the Botryosphaeriaceae are probably most wellknown as being destructive blight and canker pathogens of planted hosts (Luo et al., 2019). In agricultural settings, for example, they infect a large number of fruit and nut crops, such as almond (Inderbitzin et al., 2010; Gramaje et al., 2012; Nouri et al., 2018; Holland et al., 2020), apple (Phillips et al., 2012), avocado (McDonald et al., 2009), citrus (Linaldeddu et al., 2015), grapevine (Urbez-Torres, 2011), olive (Úrbez-Torres et al., 2013), pistachio (Michailides, 1991; Nouri et al., 2019), and walnut (Chen S. et al., 2014). In forest plantations in Australia and South Africa, for example, they infect Eucalyptus spp. and Pinus spp. (Slippers et al., 2007). Infection is through either wounds to green and woody tissues or through natural openings in flowers, fruit, leaves, and shoots. The pathogens produce enzymes and/or toxins that kill cells and tissues of the various plant organs they attack. Infections of woody tissues of perennial hosts, either deep in the wood or just below the bark, can lead to stunted shoot growth, with eventual shoot death or "dieback."

Ecological genomic comparisons of phytopathogenic and saprobic fungi suggest that the former possess expanded gene families that generally fall into two main functional categories: (1) lytic capabilities (Massonnet et al., 2018) and (2) putative transporters (Powell et al., 2008). Fungal lignin peroxidases, peroxidases, laccases, and polyphenol oxidases allow fungi to gain access to nutrients and to protect themselves from host defenses while growing in wood (Mayer, 2006; Martínková et al., 2016; Valette et al., 2017). Pathogenic species with the ability to enzymatically decompose a broader diversity of cell wall carbohydrates might be expected to more rapidly colonize, kill, and/or decompose host tissue. Membrane transporters of fungal plant pathogens also play important roles in exporting virulence factors involved in pathogenesis, influx of nutrients, and efflux of host-derived defense antimicrobial compounds (Denny and VanEtten, 1983; Denny et al., 1987). Previous genomic comparisons of phylogenetically diverse wood-infecting pathogens of grape revealed expansions in the repertoire of cell-wall degrading enzymes called carbohydrate-active enzyme (CAZyme) gene families, whose protein products are involved in the synthesis, degradation, and/or modification of glycosidic bonds of plant cell wall constituents, including the main components of wood, cellulose, hemicelluloses, lignin (MoralesCruz et al., 2015), and significantly so in Neof. Further, a recent genomic annotation and in planta transcriptomic study of putative virulence factors of Neof. parvum during wood colonization revealed 567 protein-coding genes belonging to 52 different CAZyme families with glycoside hydrolases (GHs), which made up approximately $50 \%$ of the pathogen's cell-wall degrading repertoire (Massonnet et al., 2018). Likewise, Yan et al. (2018) identified 820 CAZymes with at least 10 families that have experienced expansion in the genome of Lasiodiplodia theobromae with GHs representing the largest super family involved in the modification of plant cell wall carbohydrates. Genome comparisons of $B$. dothidea, L. theobromae, and Neof. parvum revealed that the genome of $L$. theobromae, the most virulent of the three species, is expanded in gene families associated with membrane transport, mainly ATP-bindingcassette (ABC family), and major facilitator super (MFS) families 
(Yan et al., 2018). That same study reported 17 membrane transport genes that were significantly up-regulated upon host recognition including amino acid transporters and sugar porters. The largest transporter families reported in the genome of Neof. parvum include MFS, Peroxisomal Protein Importer (PPI) family, and the ABC superfamily (Massonnet et al., 2018).

In this study we analyze the genome sequences of seventeen Botryosphaeriaceae species representing six genera (Botryosphaeria, Diplodia, Dothiorella, Lasiodiplodia, Neofusicoccum, and Neoscytalidium), which are wood-canker pathogens that attack horticultural crops, namely grape, pistachio, Prunus species (almond and stone fruits apricot, peach, and plum), and walnut. Our objective is to examine through phylogenomic comparisons this comprehensive set of species on one host, grape, to better understand the evolutionary trends within this important fungal family, especially as it pertains to the gene space involving pathogenesis of woody tissues and fungal virulence.

\section{MATERIALS AND METHODS}

\section{Isolate Collection and Species Confirmation}

All fungal isolates utilized in this study were obtained from internal wood cankers of symptomatic hosts following the protocol of Baumgartner et al. (2013) (Table 1). Total genomic DNA was extracted following Morales-Cruz et al. (2018). The internal transcribed spacer (ITS) and translation elongation factor (TEF) loci were amplified for each isolate via PCR using primers ITS5/ITS4 (White et al., 1990) and EF1-688F/EF1-1251R (Alves et al., 2008). TEF and ITS sequences of each species (including type specimen sequences downloaded from GenBank) were concatenated and aligned using MUSCLE v3.8.31 (Edgar, 2004) with default parameters. The alignment was cleaned with GBlocks v. 0.91b (Castresana, 2000) with a minimum block's length of $5 \mathrm{bp}$ and half of the gaps allowed. PhyML (Guindon et al., 2010) was used to calculate the maximum likelihood tree using 100 bootstrap replications, HKY85 substitution model and the subtree-pruning-regrafting method for searching for optimal tree topology. The resulting tree was visualized and edited for presentation using FigTree v1.4.1 (Rambaut, 2012).

\section{Sequencing and Genomes Assemblies}

DNA extraction was done following the methods used by Morales-Cruz et al. (2015) using the axenic cultures of the isolated fungi and a CTAB protocol. Sequencing libraries were prepared and sequenced as described in Morales-Cruz et al. (2015). After adapter ligation, libraries were size selected to 550-600 bp using a double-sided size selection with Ampure XP magnetic beads (Beckman Coulter, United States) to remove unused adapter and adapter dimer. Sequencing was carried out on an Illumina HiSeq4000 machine at the DNA Technologies Core at UC Davis. Paired-end reads of $150 \mathrm{bp}$ in length were generated. Raw reads were trimmed for quality $(Q>30)$ and adapter removal using Trimmomatic v0.36 (Bolger et al., 2014) with options LEADING:3 TRAILING:3
SLIDINGWINDOW:4:20 MINLEN:100. Assembly of highquality reads was made using SPAdes v3.9 (Bankevich et al., 2012) with the careful option and automatic read coverage cutoff. Assembly completeness was assessed using the Core Eukaryotic Genes Mapping Approach (CEGMA v.2.5; Parra et al., 2007) and Benchmarking Universal Single-Copy Orthologs (BUSCO v.1.1; Simão et al., 2015) analysis. RepeatMasker v.4.06 (Smit et al., 1996-2015) with default parameters was used to mask repeats. Gene model prediction was performed with Augustus v.3.2.1 (Stanke et al., 2006) with default parameters and using Neof. parvum gene model as training set. Sequencing data are available at NCBI (BioProject PRJNA673527). Sequencing data of Diplodia seriata (Morales-Cruz et al., 2015) and Neof. parvum (Massonnet et al., 2018) can be retrieved from NCBI under BioProject PRJNA261773 and PRJNA321421, respectively. All genome assemblies and gene models are publicly available at Zenodo (doi: 10.5281/zenodo.4417445).

\section{Functional Annotation}

The general annotation of the predicted proteins was assigned based on the similarities with peptides in the GenBank with Blast2GO (Conesa et al., 2005), and to conserved domains in Pfam database (Finn et al., 2016). The functional annotation (Supplementary Table 3) was assigned based on the databases and parameters presented in Supplementary Table 4. CAZymes were annotated with the dbCAN2 (Zhang et al., 2018). The signal peptides were predicted using SignalP 5.0 (Armenteros et al., 2019). The proteins with annotation in both databases were annotated as secreted CAZymes. Secondary metabolites clusters were annotated using antiSMASH 5.0 (Blin et al., 2019). Peroxidases were annotated using a specialized database for fungi called fPoxDB (Choi et al., 2014). CYPED 6.0 was used to annotate the Cytochrome 4450 proteins (Fischer et al., 2007). At last, the proteins involved in transportation functions were annotated using the TCDB (Saier et al., 2006, 2016).

\section{Construction of a Clock-Calibrated Phylogenetic Tree}

Seventy-three single copy peptides used in Floudas et al. (2012) for fungal phylogeny reconstruction were extracted from the reference strain Saccharomyces cerevisiae 2S88C Genome Release 64-2-1 (downloaded from http://www.yeastgenome.org). All these peptides were compared using BLASTP (v.2.6.0+) against the seventeen Botryosphaeriaceae species and two wood-decay basidiomycetes that colonize grape: pathogenic, wood-rotting fungus (with characteristics of both white-rot and brown-rot fungi) Fomitiporia mediterranea and saprobic, white-rot fungus Stereum hirsutum. Fomitiporia mediterranea is one of a complex of pathogens that causes the grapevine trunk disease Esca in Europe, whereas the pathogenicity of St. hirsutum to grape is not known (Fischer, 2006). Twenty-one proteins had exactly one top hit in all the species. The rest of the seventy-three initial proteins were excluded because they were either not present in all the species or had paralogs. Each set of orthologous proteins was aligned using MUSCLE v3.8.31 (Edgar, 2004). Alignments were concatenated and cleaned using GBlocks v. 
TABLE 1 | Genome assembly summary statistics of the Botryosphaeriaceae species analyzed.

\begin{tabular}{|c|c|c|c|c|c|c|c|}
\hline Species (isolate ID) & Isolated from & Assembly size (Mbp) & N. scaffold & N50 (kbp) & L50 (Scaffold \#) & CEGMA $^{\star \star \star}$ & BUSCO ${ }^{* * *}$ \\
\hline Botryosphaeria dothidea (0053) & Grape & 46 & 2,425 & 506 & 28 & $99 \%$ & $98 \%$ \\
\hline Diplodia mutila (SBen820) & Grape & 46 & 4,003 & 175 & 67 & $98 \%$ & $98 \%$ \\
\hline Diplodia seriata (DS831)* & Grape & 37 & 811 & 301 & 39 & $98 \%$ & $98 \%$ \\
\hline Dothiorella iberica (Wolf833) & Apricot & 37 & 636 & 412 & 28 & $97 \%$ & $98 \%$ \\
\hline Dothiorella sarmentorum (SBen806) & Apricot & 42 & 1,664 & 242 & 57 & $97 \%$ & $98 \%$ \\
\hline Dothiorella viticola (Wint804) & Grape & 37 & 2,477 & 482 & 25 & $98 \%$ & $98 \%$ \\
\hline Lasiodiplodia citricola (06I-35) & Walnut & 44 & 216 & 1,067 & 13 & $97 \%$ & $98 \%$ \\
\hline Lasiodiplodia exigua (UCR-LT5) & Grape & 44 & 340 & 720 & 15 & $98 \%$ & $98 \%$ \\
\hline Lasiodiplodia missouriana (09-C092) & Grape & 44 & 324 & 883 & 17 & $98 \%$ & $98 \%$ \\
\hline Lasiodiplodia theobromae (MXBCL28) & Grape & 44 & 193 & 883 & 16 & $99 \%$ & $98 \%$ \\
\hline Neofusicoccum australe (UCR-NA2) & Grape & 42 & 2,218 & 385 & 35 & $99 \%$ & $98 \%$ \\
\hline Neofusicoccum hellenicum (02-K91) & Pistachio & 43 & 221 & 768 & 19 & $98 \%$ & $98 \%$ \\
\hline Neofusicoccum mediterraneum (Wint817) & Grape & 42 & 196 & 551 & 24 & $99 \%$ & $98 \%$ \\
\hline Neofusicoccum nonquaesitum (05-A04) & Walnut & 43 & 316 & 667 & 19 & $99 \%$ & $98 \%$ \\
\hline Neofusicoccum parvum (UCD646So)** & Grape & 43 & 2,452 & 168 & 74 & $99 \%$ & $98 \%$ \\
\hline Neofusicoccum vitifusiforme (05-H02) & Walnut & 42 & 288 & 506 & 24 & $98 \%$ & $98 \%$ \\
\hline Neoscytalidium dimidiatum (UCR-Neo1) & Grape & 42 & 478 & 419 & 31 & $100 \%$ & $98 \%$ \\
\hline
\end{tabular}

0.91b (Castresana, 2000; maximum number of contiguous nonconserved positions $=4$, minimum length of a block $=10$ ), reducing the initial 21,008 positions to 12,066 informative positions. Clean alignments were imported into BEAUti v1.10.4 to prepare them for BEAST v1.10.4 analysis (Bouckaert et al., 2014). Monophyletic partitions were set for Ascomycota, Basidiomycota, and Dothideomycetes species. Calibrations points were set to 588 and 350 mya on Ascomycota and Dothideomycetes partition, respectively, according to Beimforde et al. (2014). Six MCMC chains of 1,000,000 steps were launched on BEAST (WAG substitution model, 4 Gamma Categories + Invariant sites, Lognormal relaxed clock, Calibrated Yule Model). The resulting trees were concatenated with LogCombiner v1.10.4 (Bouckaert et al., 2014) and a consensus tree was obtained from TreeAnnotator v1.10.4 (Bouckaert et al., 2014; Supplementary Figure 1). FigTree v1.4.1 (Rambaut, 2012) and Inkscape v.1.0.1 (Inkscape Project, 2020) were used to edit the tree for figure presentation.

\section{Computational Analysis of Gene Family Evolution (CAFE)}

BLASTP $\left(e\right.$-value $<10^{-6}$ ) was used to group proteins in families based on sequence similarity followed by Markov clustering with MCL (Van Dongen, 2000; Enright et al., 2002). The 10,158 families with at least one protein in no less than four species were used with the clock calibrated tree as input for the CAFE v.4.2.1 (De Bie et al., 2006) analysis. CAFE was run in the default mode with the option -s to optimize the lambda parameter to 0.00155948837239 , and a $P$-value threshold of 0.01 (option -p). To evaluate significant expansions or contractions of a specific branch, Viterbi $P$-values were calculated for each significant family.

\section{Phylogenetic Principal Component Analysis}

The phyl.pca function of the phytools R package (Revell, 2012) was used to create the phylogenetic PCAs. The inputs for his function were the clock calibrated tree and protein matrices of CAZymes and secondary metabolite clusters.

\section{Pathogenicity Tests}

The pathogenicity of 17 species of Botryosphaeriaceae was evaluated on potted grapevines (Vitis vinifera 'Pinot noir' clone 777) in replicate experiments in the greenhouse $(18$ treatments $\times 10$ replicate plants per treatment $\times 2$ experiments $=360$ total plants). Hardwood cuttings obtained from a commercial nursery were propagated in May/June 2016 following the protocol of Travadon et al. (2013). Inoculations took place after callusing and before planting in pots in the greenhouses. For inoculations, the commonly used agar plug method was employed (e.g., Chacón et al., 2020). This method has been shown to produce lower variability in lesion length than the method with mycelial suspensions for the pathogens Neof. parvum and Di. seriata (Guan et al., 2016). For inoculations, a power drill was used to wound ( $5 \mathrm{~mm}$ wide $\times 3 \mathrm{~mm}$ deep) the cutting, approximately $2 \mathrm{~cm}$ below the apical node. A $5-\mathrm{mm}$ agar plug from a 7-day culture on PDA was aseptically inserted into the wound and sealed with Vaseline and parafilm to prevent inoculum desiccation. Cuttings were coated in melted paraffin wax (Gulf Wax; Royal Oak Enterprises, LLC, Roswell, GA, United States) and potted in a sterile potting mix amended with slow-release fertilizer (Osmocote ${ }^{\circledR}$ Pro 24-4-9, Scotts, Marysville, $\mathrm{OH}$, United States). The plants were watered twice per week for 16 weeks. Ten plants were used for each isolate and ten plants were mock-inoculated with sterile PDA. Plants were 
arranged in a completely randomized design in two separate greenhouses at the University of California Experiment Station in Davis from June 2016 to October 2016 [natural sunlight photoperiod, $25 \pm 1 \mathrm{C}$ (day), $18 \pm 3 \mathrm{C}$ (night)]. The second experiment was initiated 1 week after the first experiment. The length of internal wood discoloration extending out from the inoculation site up and down the stem (lesion length) was measured approximately 16 weeks after inoculation in October 2016. First, plants were inspected for foliar symptoms. Then the newly developed green shoots, roots, and bark of each plant were removed and discarded, and the woody stems were surface sterilized in 1\% sodium hypochlorite for $2 \mathrm{~min}$ and rinsed with deionized water. The length of each stem was recorded and cut longitudinally to expose wood discoloration, the length of which was measured with a digital caliper. From each plant, ten small wood pieces were cut from the margin of the lesion with flame-sterilized scalpels and plated onto PDA in an attempt to recover the inoculated fungi. Inoculated pathogens, identified based on colony morphology, were re-isolated from all samples.

Lesion lengths were used as a measure of pathogenicity. Normality and homogeneity of variances were evaluated using Shapiro-Wilk's and Levene's tests, respectively. ANOVA was used to determine whether there were differences in lesion length among treatments. ANOVA was performed in $\mathrm{R}$ using the lesion size as a function of the inoculation treatment and the experiment. Means were compared for significant effects $(P<0.05)$ by Tukey's HSD post hoc test.

\section{RESULTS}

\section{Genome Assembly, Gene Prediction, and Virulence Factor-Focused Functional Annotation}

To expand the genomic information for Botryosphaeriaceae, we de novo assembled the genomes of fifteen species isolated from multiple hosts. We included the previously published genomes of Neof. parvum and Di. seriata in the comparative genomics analysis (Table $\mathbf{1}$ and Supplementary Table 1). For all seventeen species, pathogenicity was evaluated using inoculations of potted grapevines (Figure 1). All seventeen species produced dark necrotic lesions in the woody stems extending upward and downward from the point of inoculation at 15 weeks post inoculation. Overall, Lasiodiplodia and Neofusicoccum spp. were the most aggressive, while Diplodia and Dothiorella spp. caused the smallest lesions.

All genomes were sequenced using Illumina technology at coverage $171 \pm 10 \times$ (Supplementary Table 1). On average, sequencing Illumina reads were assembled into 1,066 \pm 308 scaffolds (N50 length: $577.64 \pm 64.53 \mathrm{kbp}$; L50 scaffold count: $27.9 \pm 4$ scaffolds). The total genome assembly size varied from $37 \mathrm{Mbp}$ for Dothiorella viticola to $46 \mathrm{Mbp}$ for $B$. dothidea with an average of $42.37 \pm 0.69 \mathrm{Mbp}$. The expected and assembled genome size had a discrepancy of less than ten percent on average ( $4.4 \pm 2.2 \mathrm{Mb}$ ), which suggests near completeness of the assemblies (Supplementary Table 1). This result was confirmed

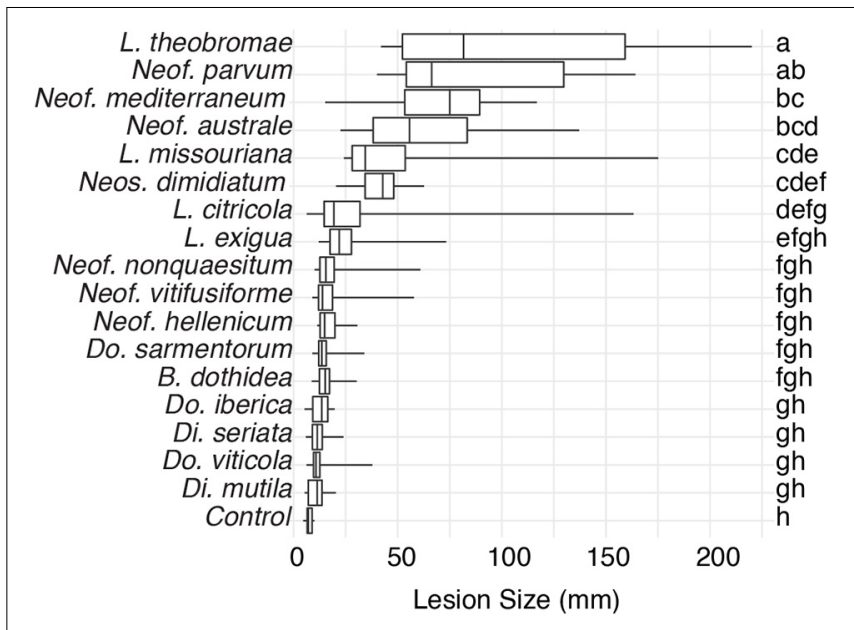

FIGURE 1 | Box plots illustrating the distribution of lesion sizes caused by individual isolates of the 17 Botryosphaeriaceae species after 4 months incubation in potted grapevine plants grown under greenhouse conditions. Bars with the same letter were not significantly different at $P<0.05$ according to Tukey's test.

by CEGMA (Parra et al., 2007) and BUSCOs (Simão et al., 2015) analyses, which reported an average $98.3 \pm 0.2 \%$ and $98.1 \pm 0.1 \%$ completeness, respectively (Table 1). Interspersed repeats only accounted for $1.87 \pm 0.003 \%$ of the genome assemblies. Among the classified elements, long-terminal-repeats (LTR) were the most abundant, ranging from a total of $315 \mathrm{kbp}$ in $B$. dothidea to $26 \mathrm{kbp}$ in Neoscytalidium dimidiatum (Supplementary Table 2). The predicted protein-coding genes in the seventeen genomes varied from 10,827 in Dothiorella iberica to 13,492 in Dothiorella sarmentorum. On average 12,193 $\pm 193 \mathrm{CDS}$ were found per species (Table 2).

The predicted genes of the seventeen genomes were annotated using general databases for protein domains (Pfam), gene ontology (GO), as well as more specialized databases related to putative virulence factors. The last group included carbohydrateactive enzymes (CAZymes), cytochrome P450s, peroxidases, usually associated with host colonization and wood degradation, and secondary metabolism gene clusters, including toxins production, and cellular transporters (Supplementary Table 4 and Table 3). A total of 229,251 predicted protein-coding genes were annotated (Table 3 ).

\section{Carbohydrate-Active Enzymes Are Especially Abundant in the Genomes of Neofusicoccum Species}

A wide variety of monosaccharides can be linked to many different types of molecules (proteins, lipids, nucleic acids and, sugar themselves) and converting these glycoconjugates into one of the most structurally diverse substrates (Cantarel et al., 2009). CAZymes are the group of enzymes responsible for the assembly and breakdown of these diverse substrates (Lombard et al., 2014). Not all CAZymes contribute to the pathogenicity of the microorganisms, however, predicting them 
TABLE 2 | Gene model predictions statistics of the Botryosphaeriaceae species analyzed.

\begin{tabular}{|c|c|c|c|c|c|c|}
\hline Species & Repeat content (bp) & N. CDS & $\begin{array}{c}\text { Mean protein } \\
\text { size (AA) }\end{array}$ & BUSCO* & $\begin{array}{c}\text { Mean gene } \\
\text { density } \\
\text { (genes/10 kbp) }\end{array}$ & SD \\
\hline Botryosphaeria dothidea & $2,608,021(5.67 \%)$ & 12,424 & 478 & $98 \%$ & 2.14 & 1.9 \\
\hline Diplodia mutila & $2,877,891(6.28 \%)$ & 11,947 & 491 & $98 \%$ & 1.74 & 1.9 \\
\hline Di. seriata & $1,144,284(3.05 \%)$ & 11,085 & 495 & $98 \%$ & 2.93 & 1.8 \\
\hline Dothiorella iberica & $1,350,049(3.69 \%)$ & 10,827 & 491 & $98 \%$ & 3.02 & 1.8 \\
\hline Do. sarmentorum & $1,687,353(4.02 \%)$ & 13,942 & 474 & $98 \%$ & 2.90 & 2.5 \\
\hline Do. viticola & $950,252(2.60 \%)$ & 11,235 & 473 & $98 \%$ & 2.19 & 1.9 \\
\hline Lasiodiplodia citricola & 825,529 (1.89\%) & 12,376 & 492 & $98 \%$ & 3.19 & 1.4 \\
\hline L. exigua & $771,071(1.77 \%)$ & 12,399 & 492 & $98 \%$ & 3.12 & 1.5 \\
\hline L. missouriana & 833,148 (1.89\%) & 12,448 & 494 & $98 \%$ & 3.12 & 1.5 \\
\hline L. theobromae & 820,166 (1.88\%) & 12,434 & 493 & $98 \%$ & 3.20 & 1.4 \\
\hline Neofusicoccum australe & $2,055,816(4.92 \%)$ & 12,104 & 488 & $98 \%$ & 2.29 & 1.9 \\
\hline Neof. hellenicum & $1,078,449(2.53 \%)$ & 12,433 & 486 & $98 \%$ & 3.27 & 1.4 \\
\hline Neof. mediterraneum & $960,302(2.26 \%)$ & 12,541 & 484 & $98 \%$ & 3.36 & 1.4 \\
\hline Neof. nonquaesitum & $1,010,201(2.35 \%)$ & 12,602 & 487 & $98 \%$ & 3.24 & 1.5 \\
\hline Neof. parvum & $2,170,098(5.00 \%)$ & 12,679 & 485 & $98 \%$ & 2.27 & 1.9 \\
\hline Neof. vitifusiforme & $1,405,151(3.37 \%)$ & 12,112 & 485 & $98 \%$ & 3.22 & 1.5 \\
\hline Neoscytalidium dimidiatum & $1,099,801(2.61 \%)$ & 11,067 & 478 & $98 \%$ & 3 & 1.5 \\
\hline
\end{tabular}

*Percentage of complete BUSCO peptides found in the predicted proteome.

TABLE 3 | Number of protein coding genes annotated per functional category.

\begin{tabular}{|c|c|c|c|c|c|c|c|c|c|c|}
\hline Species & $\begin{array}{c}\text { Total } \\
\text { genes }\end{array}$ & $\begin{array}{l}\text { Annotated } \\
\text { genes }\end{array}$ & $\begin{array}{c}\text { Secondary } \\
\text { metabolites } \\
\text { involved genes }\end{array}$ & P450s & CAZymes & $\begin{array}{l}\text { Secreted } \\
\text { CAZymes }\end{array}$ & Peroxidases & $\begin{array}{c}\text { Signal } \\
\text { Peptides }\end{array}$ & Transporters & $\begin{array}{c}\% \text { Secreted } \\
\text { CAZymes of } \\
\text { total } \\
\text { secreted }\end{array}$ \\
\hline Botryosphaeria dothidea & 12,424 & 11,877 & 809 & 857 & 485 & 280 & 56 & 1,341 & 2,505 & $20.9 \%$ \\
\hline Diplodia mutila & 11,947 & 11,240 & 407 & 675 & 433 & 242 & 55 & 1,198 & 2,362 & $20.2 \%$ \\
\hline Di. seriata & 11,085 & 10,535 & 300 & 620 & 432 & 251 & 53 & 1,114 & 2,238 & $22.5 \%$ \\
\hline Dothiorella iberica & 10,827 & 10,237 & 374 & 609 & 399 & 229 & 41 & 1,029 & 2,185 & $22.3 \%$ \\
\hline Do. sarmentorum & 13,942 & 13,226 & 457 & 652 & 487 & 259 & 50 & 1,596 & 3,143 & $16.2 \%$ \\
\hline Do. viticola & 11,235 & 10,663 & 283 & 594 & 395 & 218 & 46 & 1,053 & 2,339 & $20.7 \%$ \\
\hline Fomitiporia mediterranea & 11,338 & 11,338 & 205 & 639 & 315 & 178 & 52 & 780 & 1,985 & $22.8 \%$ \\
\hline Lasiodiplodia citricola & 12,376 & 11,831 & 564 & 785 & 465 & 266 & 54 & 1,298 & 2,492 & $20.5 \%$ \\
\hline L. exigua & 12,399 & 11,838 & 578 & 785 & 474 & 271 & 55 & 1,287 & 2,499 & $21.1 \%$ \\
\hline L. missouriana & 12,448 & 11,902 & 572 & 787 & 470 & 267 & 54 & 1,305 & 2,507 & $20.5 \%$ \\
\hline L. theobromae & 12,434 & 11,832 & 610 & 784 & 465 & 270 & 54 & 1,279 & 2,490 & $21.1 \%$ \\
\hline Neofusicoccum australe & 12,104 & 11,709 & 654 & 800 & 488 & 291 & 61 & 1,334 & 2,530 & $21.8 \%$ \\
\hline Neof. hellenicum & 12,433 & 12,015 & 662 & 868 & 501 & 281 & 62 & 1,369 & 2,546 & $20.5 \%$ \\
\hline Neof. mediterraneum & 12,541 & 12,052 & 658 & 843 & 504 & 288 & 61 & 1,372 & 2,549 & $21.0 \%$ \\
\hline Neof. nonquaesitum & 12,602 & 12,229 & 661 & 918 & 514 & 296 & 60 & 1,394 & 2,604 & $21.2 \%$ \\
\hline Neof. parvum & 12,679 & 12,328 & 639 & 908 & 504 & 298 & 59 & 1,393 & 2,588 & $21.4 \%$ \\
\hline Neof. vitifusiforme & 12,112 & 11,715 & 575 & 817 & 501 & 289 & 62 & 1,322 & 2,492 & $21.9 \%$ \\
\hline Neoscytalidium dimidiatum & 11,067 & 10,701 & 489 & 746 & 452 & 247 & 48 & 1,139 & 2,357 & $21.7 \%$ \\
\hline Saccharomyces cerevisiae & 5,917 & 5,917 & 48 & 215 & 136 & 44 & 21 & 306 & 1,478 & $14.4 \%$ \\
\hline Stereum hirsutum & 14,066 & 14,066 & 426 & 652 & 394 & 230 & 52 & 1,070 & 2,150 & $21.5 \%$ \\
\hline
\end{tabular}

in conjunction with signal peptides is widely used to obtain information about plant pathogen cell wall degrading enzymes (Floudas et al., 2012; Suzuki et al., 2012; Blanco-Ulate et al., 2014; Jones et al., 2014; Morales-Cruz et al., 2015). An average of $20.9 \pm 0.3 \%$ of the predicted secreted proteins among all seventeen Botryosphaeriaceae genomes shared similarity with the CAZymes in the dbCAN2 database (Zhang et al., 2018). Glycoside Hydrolases (GH) and Auxiliary Activity CAZymes (AA) were the two groups with the most predicted proteins. GHs were especially abundant in Neofusicoccum spp. with an average of $336 \pm 4$ proteins compared to $303 \pm 7$ for the rest of the Botryosphaeriaceae species in this study (Supplementary 
Table 5). A total of 15 putative genes of $\mathrm{GH} 3$ were present in Neofusicoccum nonquaesitum and Lasiodiplodia missouriana, as well as 14 in Neof. parvum, Lasiodiplodia citricola, and Lasiodiplodia exigua. GH3 and GH43 families activities include $\beta$-glucosidases, $\beta$-xylosidases, glucanases, L-arabinofuranosidase, galactanase and others related to the hydrolysis of plant cell wall components into more simple sugars (Faure, 2002; Polizeli et al., 2005; Cairns and Esen, 2010; Knob et al., 2010; Sampedro et al., 2017).

Auxiliary activities (AAs) were also more abundant in Neofusicoccum $(127 \pm 3)$ than the rest of the Botryosphaeriaceae species $(100 \pm 4)$. The AA3 family was the most abundant with numerous copies in the genus Neofusicoccum (Figure 2), ranging from 21 to 26 predicted proteins in Neof. parvum (UCD646So). The genome of $B$. dothidea was predicted to possess 23 AA3 proteins. The AA3 and AA9 families include cellobiose dehydrogenases, alcohol oxidases, pyranose oxidase, acting over more complex substrates of the plant cell wall like cellulose and/or lignin (Daniel et al., 1994; Henriksson et al., 2000; Harreither et al., 2011; Hernández-Ortega et al., 2012).

\section{Neofusicoccum, Botryosphaeria, and Lasiodiplodia Species Encode the Largest Number of Predicted P450s}

Cytochrome P450 enzyme evolution is thought to contribute to the adaptation of organisms to new ecological niches. The functions may vary from primary metabolism, detoxification of xenobiotic compounds, to producing a vast variety of secondary metabolites (Črešnar and Petrič, 2011; Moktali et al., 2012; Chen W. et al., 2014). These features sometimes play essential roles in pathogenesis (Črešnar and Petrič, 2011; Moktali et al., 2012). The P450s were classified in superfamilies as described by Fischer et al. (2007). Neofusicoccum, Botryosphaeria, and Lasiodiplodia species encoded a larger number of predicted P450 (859 $\pm 20,857$, and $785 \pm 1$, respectively) compared to Diplodia and Dothiorella species $(648 \pm 28$ and $618 \pm 17$, respectively). Neof. nonquaesitum and Neof. parvum showed the highest number of predicted P450s genes with 918 and 908, respectively (Table 3 and Supplementary Table 6). CYP53, CYP51, and CYP504 were the most abundant across all the species. CYP53 was especially numerous in Neofusicoccum (137 \pm 4 genes), Lasiodiplodia (128 \pm 1 gene), and Botryosphaeria (119 \pm 4 genes) species compared to the other genera (93 \pm 8 genes). On the other hand, the CYP51 was very consistent in the Botryosphaeriaceae family (from 93 to 105 genes). Other superfamilies like CYP706, CYP102, and CYP3 show the same pattern of higher representation in Neofusicoccum, Lasiodiplodia, and Botryosphaeria than in Diplodia and Dothiorella species.

\section{Peroxidases Are Most Abundant in the Genomes of Neofusicoccum Species}

Fungal peroxidases are oxidoreductases that catalyze the oxidation of various compounds ranging from ligninolysis to the detoxification of host-derived reactive oxygen species and have been shown to contribute to virulence (Molina and
Kahmann, 2007; Guo et al., 2010; Choi et al., 2014). The annotation of these peroxidases was based on the manually curated Fungal Peroxidases Database fPoxDB (Choi et al., 2014). Neofusicoccum species encoded the largest number of predicted peroxidases $(61 \pm 0)$, followed by Lasiodiplodia, Botryosphaeria, and Diplodia with an average of $54 \pm 1$ annotated genes (Table 3). Dothiorella, with only $46 \pm 3$ was the genus with the least number of annotated peroxidases in the Botryosphaeriaceae (Supplementary Table 7). Hybrid Ascorbate-Cytochrome C peroxidases were more abundant in Neofusicoccum, Botryosphaeria, and Lasiodiplodia, ranging from 8 to 11 genes, while haloperoxidases were more abundant in the genus Neofusicoccum (11 \pm 0 genes).

\section{The Genomes of Botryosphaeria, Neofusicoccum, and Lasiodiplodia Species Have the Largest Number of Secondary Metabolism Gene Clusters}

Secondary metabolites play important roles in fungal development and interactions with other organisms, including plant hosts (Keller, 2019). Phytotoxic metabolites, e.g., melleins, produced by Neof. parvum both in vitro and in the wood of symptomatic grape are thought to be associated with pathogenesis (Abou-Mansour et al., 2015). In fungi, the genes encoding the functions responsible for the biosynthesis of secondary metabolites are physically grouped in clusters of contiguous genes (Brakhage, 2013; Keller, 2019), which typically comprise a central biosynthetic gene as well as genes involved in post-synthesis modification of the metabolites and cellular transport.

Using antiSMASH 5 (Blin et al., 2019), we detected an average of $43 \pm 3$ biosynthetic gene clusters (BGCs) in the seventeen Botryosphaeriaceae. The Type I Polyketide synthase cluster (T1PKS) and the Non-ribosomal peptide synthetaselike fragment (NRPS-like) together accounted for $47 \%$ of all annotated BGCs. BGCs were most abundant in Botryosphaeria, Neofusicoccum, and Lasiodiplodia species with an average of $57 \pm 8,56 \pm 1$, and $49 \pm 1$ BGCs, respectively. In these genera, we also found the larger number of genes per BGC $(11 \pm 1$, $12 \pm 0$, and $12 \pm 0$, respectively; Supplementary Table 9). In Neofusicoccum spp., $169 \pm 7$ genes were associated with T1PKS, $154 \pm 12$ in Lasiodiplodia and $175 \pm 19$ in Botryosphaeria (Figure 2). For these secondary metabolites as well as classes, we found fewer genes in the genomes of Diplodia and Dothiorella species (Supplementary Table 10).

Toxins and other secondary metabolites are exported by cellular transporters (Del Sorbo et al., 2000). Homologies with the Transporter Classification Database (TCDB; Saier et al., 2006) were used to annotate hypothetical protein transporters. Overall, the Electrochemical Potential-driven Transporters was the most prominent group across all the species representing $31 \pm 1 \%$ of the annotated transporters followed by the Primary Active Transporters (19\%) and the Incompletely Characterized Transport Systems (19\%). More specifically, The Major Facilitator Superfamily (MFS) (TCDB code 2.A.1) represented the highest number in all the species but was especially abundant 


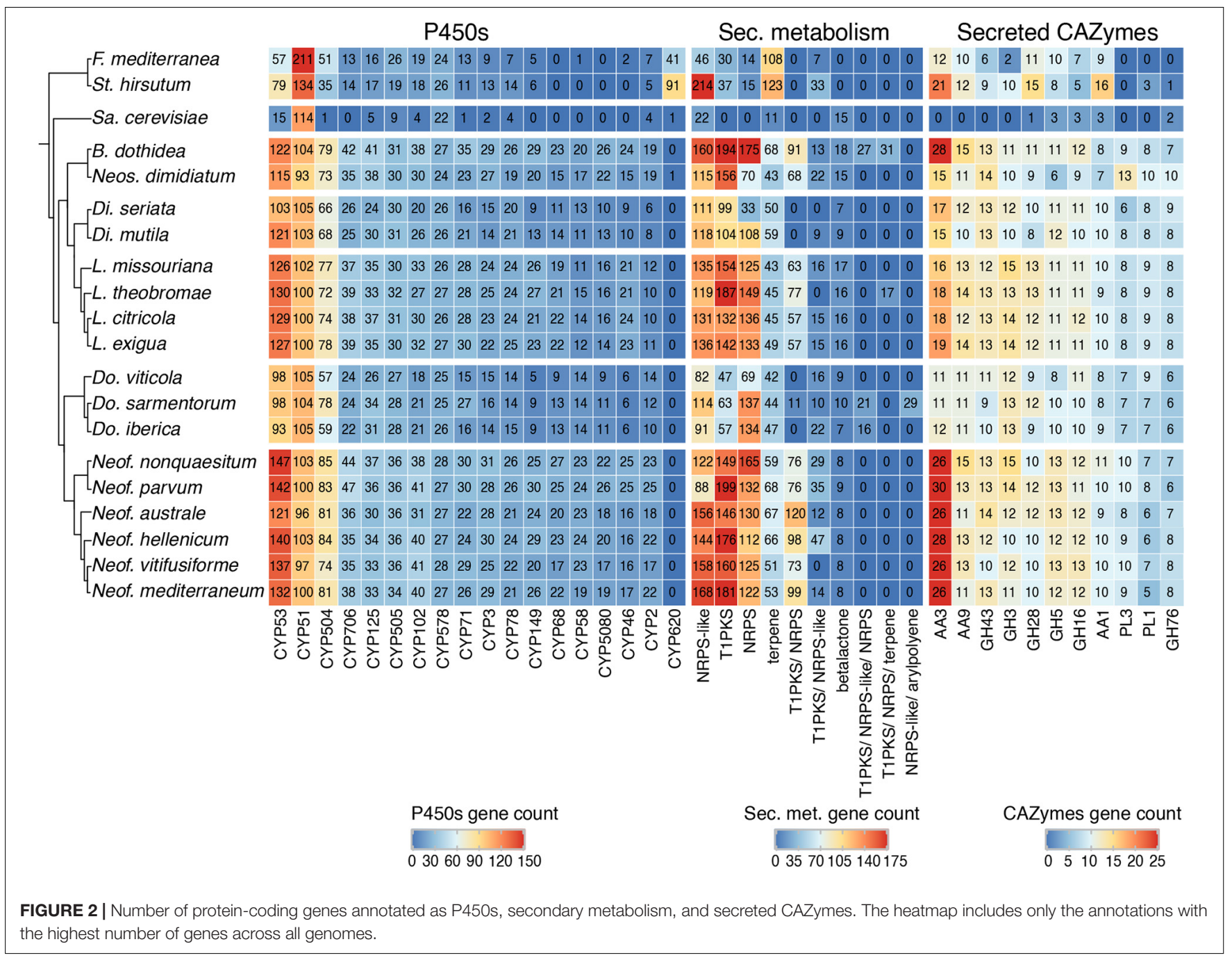

in Neofusicoccum, Lasiodiplodia, and Botryosphaeria from 455 to 514 predicted genes (Supplementary Table 8). The genome of Dothiorella sarmentorum encodes a higher number of genes in the ATP-binding Cassette (ABC; 134 genes) superfamily compared to the other fungi analyzed ( $59 \pm 1$ genes). Both MFS and $\mathrm{ABC}$ transporters can be involved in toxin secretion and defense responses (Del Sorbo et al., 2000; Perlin et al., 2014).

\section{Estimation of Gene Family Expansion and Contraction and Evaluation of Functional Enrichment}

We further evaluated the differences in putative virulence factors to identify gene families that have significantly expanded or contracted in specific lineages by statistical analysis of the evolution of the size of gene families using Computational Analysis of gene Family Evolution (CAFE; De Bie et al., 2006). CAFE estimates the global birth and death rate of gene families and identifies those families that have an accelerated rate of gain or loss (Hahn et al., 2005; De Bie et al., 2006). CAFE uses a clock-calibrated phylogenetic tree and gene family sizes in all the species' genomes as input. We included F. mediterranea and St. hirsutum, two well-known wood decay basidiomycetes related to the white-rot symptom in Esca disease of grapevines, and Sa. cerevisiae. These additional species were used as calibration points for the estimated dates of monophyletic partition of Ascomycota (588 mya) and Dothideomycetes (350 mya) as in Floudas et al. (2012) and Beimforde et al. (2014). To construct the phylogenetic tree, we identified twenty-one single-copy protein sequences that were previously used to study phylogenetic relationships across fungi (Floudas et al., 2012). The phylogenetic tree was built using a multiple alignment comprising 12,066 amino acid positions. The topology of the clock-calibrated tree was confirmed independently (Supplementary Figure 2) using ITS (Internal Transcribed Spacer) and TEF (Translation Elongation Factor), and was consistent with published ones (Phillips et al., 2008; Chen S. et al., 2014; Thambugala et al., 2014).

The gene families were computed using a Markov Cluster algorithm (MCL) that groups putative orthologs and paralogs (Enright et al., 2002). In total, 237,976 proteins of the 20 fungal genomes were clustered into gene families $\left(e\right.$-value $\left.<1 \mathrm{e}^{-6}\right)$. These family sizes and the clock calibrated tree produced by 
BEAST allowed CAFE to detect 666 families (35,498 genes) across all the species with a significantly higher than expected rate of gene gain/loss $(P \leq 0.01)$. The numbers of gene families expanded and contracted for each branch of the phylogeny are shown in Figure 3. The parent branches of the Neofusicoccum, Lasiodiplodia, and Botryosphaeria clades show a positive rate of gene gain/losses $(+0.45,+0.14$, and +0.44 , respectively), which suggest an expansion of some set of proteins. On the other hand, the parent branches of Diplodia, Dothiorella, and Basidiomycetes (Stereum and Fomitiporia) clades present a negative rate of gain losses $(-0.40,-0.49$, and -0.70 , respectively). Saccharomyces cerevisiae, as seen in previous studies (Morales-Cruz et al., 2015), showed the lowest rate with -1.63 .

The 35,498 genes in the significantly expanded or contracted families were analyzed with a Fisher's Exact test to identify functional enrichments within those families. We found that these enrichments were not always present in all the species of a clade (Figure 4). However, there are some patterns to highlight. The Lasiodiplodia clade represents an overall expansion of the transporter proteins. $B$. dothidea also shows a significant expansion of this family. On the other hand, the Diplodia and Neofusicoccum clades show an overall contraction of transporters. The Dothiorella clade and Neos. dimidiatum show no specific pattern. The expanded secondary metabolite proteins were specifically abundant in L. missouriana, L. exigua, B. dothidea, Do. sarmentorum, and Neos. dimidiatum. The P450 family was expanded mostly in Lasiodiplodia species and $B$. dothidea but contracted in Diplodia species and Neos. dimidiatum. Neofusicoccum species and B. dothidea have an important representation of expanded secreted CAZymes, Diplodia and Dothiorella represent several expanded proteins, however, the numbers in Lasiodiplodia are extremely low.

Transporter related genes in the Major Facilitator Superfamily (MFS-2.A.1) were the most enriched in all the clades analyzed (196 predicted proteins were expanded and 205 contracted). The secondary metabolite related proteins type 1 Polyketide Synthases (T1PKS) were expanded in Neos. dimidiatum, L. missouriana, L. exigua, and Do. sarmentorum, whereas Non-Ribosomal Peptide Synthetases (NRPS) were expanded in B. dothidea and Neos. dimidiatum. For the secreted CAZymes, Neof. nonquaesitum, Neofusicoccum hellenicum, and B. dothidea show an enrichment of the Auxiliary Activity family 3. Also, Do. iberica and Diplodia mutila show an enrichment of the Glycoside Hydrolase Family 3.

\section{Phylogenetically Informed Principal Component Analysis of the Expanded Gene Families Associated With Virulence Factors}

To identify similarities between species in the Botryosphaeriaceae family, a phylogenetically informed-principal component analysis (phylo-PCA) was applied to the significantly expanded families of virulence functions. These gene families were grouped into the functional categories based on the specialized databases, and the PCA was carried out using the Phyl.PCA (Revell, 2012). Phyl.PCA considers correlations among species due to phylogenetic relatedness, while correcting the matrices for nonindependence among observations (Revell and Collar, 2009). Two separate analyses were conducted using the clock-calibrated tree presented previously and the tables of the number of genes classified as secreted CAZymes (Figure 5A) and Secondary Metabolism (Figure 5B).

Due to the close phylogenetic relationship of the Botryosphaeriaceae family, the set of secreted CAZymes is remarkably similar. However, there is a clear separation of the species that are considered to be more virulent (Figure 5A), those belonging to the genera Neofusicoccum, Lasiodiplodia, and Botryosphaeria (Úrbez-Torres et al., 2008; Úrbez-Torres and Gubler, 2009). At the same time, we observe a close cluster of Neofusicoccum species which are separated from the other groups mostly by the abundance of AA1, AA3, and GH5. In addition, the genus Lasiodiplodia is tightly clustered together with $B$. dothidea. This is driven by the abundance of AA9, $\mathrm{GH} 28$, and GH3, with the last family being more abundant in Lasiodiplodia species. The close clustering of Neofusicoccum, Botryosphaeria, and Lasiodiplodia is driven mostly by their similar profile of GH16 and AA3. Neoscytalidium dimidiatum is well separated from the rest of the species by the higher presence of GH76 and PL3 proteins.

The PCA on secondary metabolite genes shows a similar separation of the most virulent genera from the others (Figure 5). Lasiodiplodia species are grouped together by similarly high profiles of T1PKS, Beta-lactone and T1PKS/NRPS clusters. Neofusicoccum species are grouped due to high numbers of terpene synthases and NRPS-like clusters. Botryosphaeria dothidea is separated because of its high abundance of NRPS, T1PKS, Terpenes, Beta-lactone, and NRPS-like clusters.

\section{DISCUSSION}

In this study, we describe the genome sequences of seventeen well-known canker-causing fungal species in the Botryosphaeriaceae. The genomes assembled coupled with in-planta experiments allowed us to start analyzing the pathogenicity levels and the virulence factor profiles within this important fungal family. The level of completeness of the assembled genomes is consistent across all the drafts based on the expected and assembled genome sizes. This behavior is also confirmed by the high representation of conserved genes (Parra et al., 2007; Simão et al., 2015). The completeness of the genomes, as well as the protein-coding genes and the repetitive DNA content, are similar to those of other woodcolonizing fungi of grape, such as Diaporthe ampelina DA912 (Morales-Cruz et al., 2015), Di. seriata DS831 (Morales-Cruz et al., 2015), and L. theobromae LA-SOL3 (Félix et al., 2019). Apart from the estimated completeness of the genomes, it is necessary to understand some of the limitations of the short reads technology, like copy number errors, chimeric contigs, and under-representation of repetitive regions (Alkan et al., 2011; Treangen and Salzberg, 2012).

The functional annotation of the seventeen Botryosphaeriaceae species presents a broad and variable 


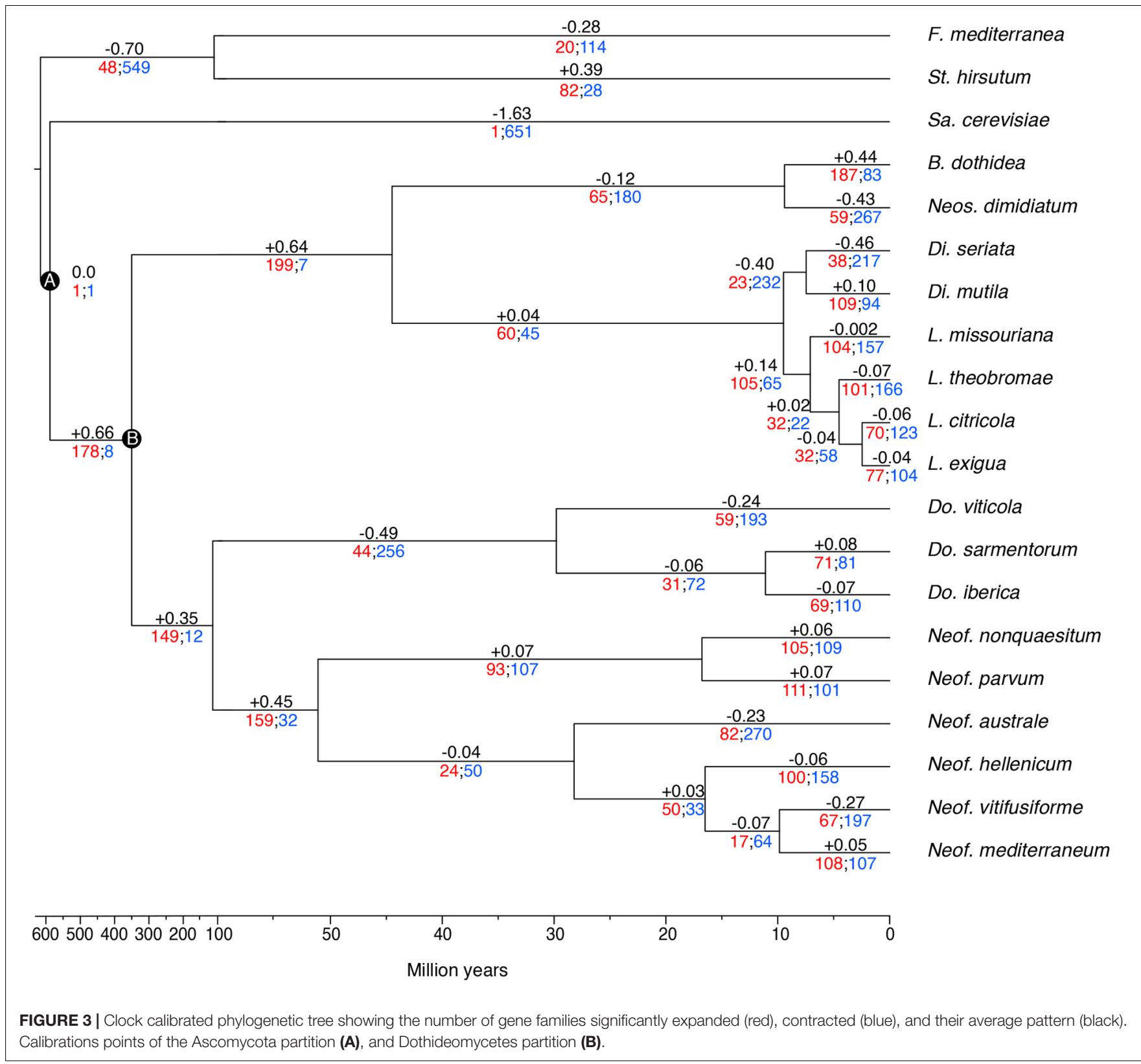

profile of virulence factors that are used in different ways by fungi to colonize and survive in their hosts (Schulze-Lefert and Panstruga, 2011; Peyraud et al., 2019). The results show a great variation in the number of genes identified with a functional category, and these differences were usually associated with the genus of each species like those observed by Baroncelli et al. (2016) in Colletotrichum and Morales-Cruz et al. (2015) in other grapevine trunk pathogens. Researchers are inclined to think that the gene content is associated with the lifestyle and the variety of hosts (Zhao et al., 2013; Lo Presti et al., 2015; Baroncelli et al., 2016). The expansion or contraction of a gene family usually occurs on functions that are under positive or negative selection. For instance, the genes related to host colonization and defense are under high pressure, therefore, it is common to encounter duplications or even losses. On the other hand, genes related to growth are more conserved and usually selected against these changes (Wapinski et al., 2007). Gene duplication events are crucial as they are considered to be one of the main processes that generate functional innovation (Zhang, 2003; Ohno, 2013). This process plays one of the most important roles in fungal adaptation and divergence (Gladieux et al., 2014).

Host colonization during infection is mostly driven by gene expression of some groups of well-known proteins, namely, the secreted CAZymes, cytochrome P450 monooxygenases, peroxidases, and secondary metabolite-producing proteins (Massonnet et al., 2018). The Botryosphaeriaceae family has a variable profile of these sets of genes, with the most virulent and aggressive species having, on average, greater 

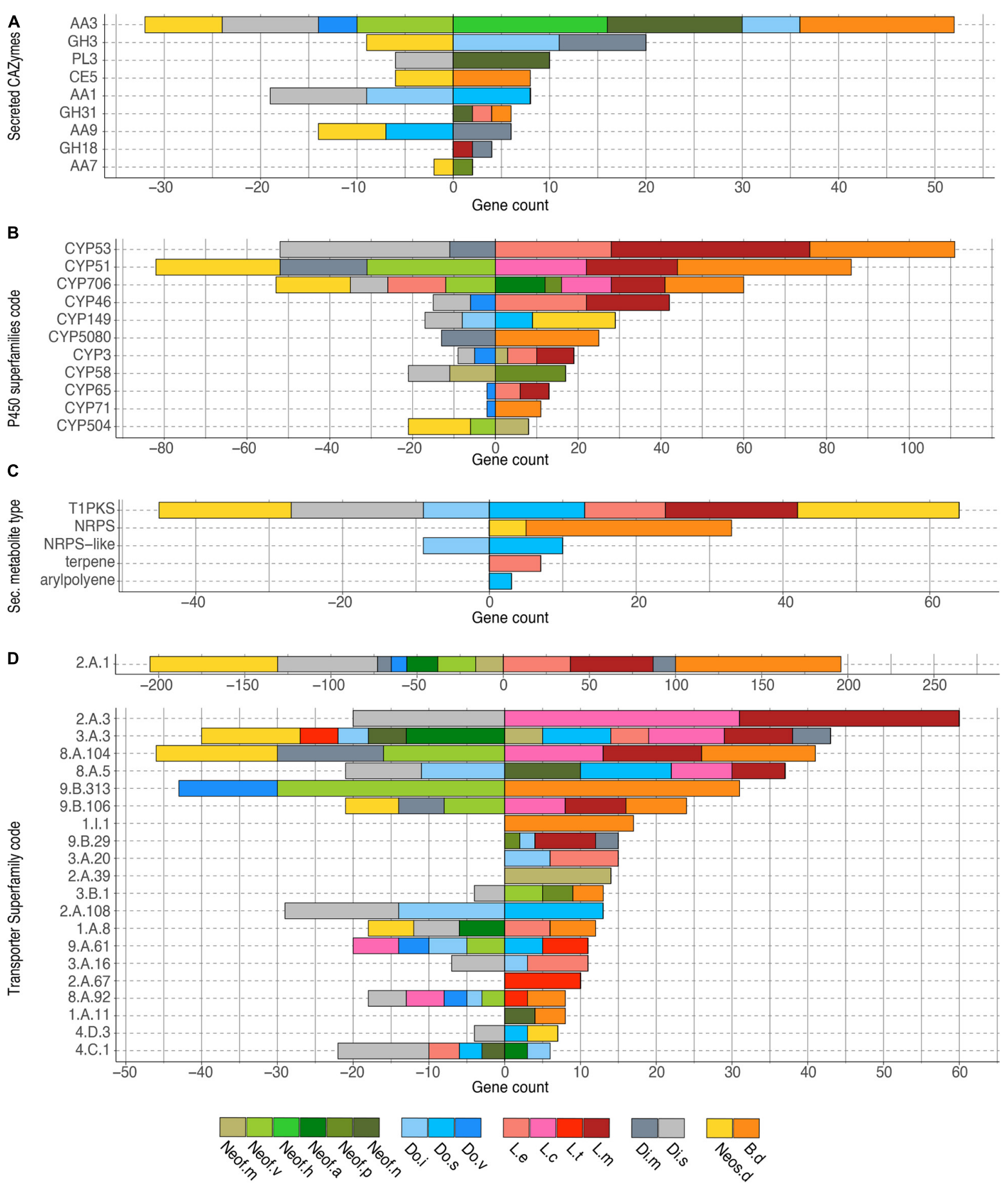

FIGURE 4 | Bar plot of the counts of genes annotated in each group of significantly expanded functional category. (A) Secreted CAZymes, (B) P450 superfamilies, (C) Secondary metabolite type, and (D) Transporter superfamilies. Only genes significantly overrepresented $(P<0.01)$ in the gene families expanded in the Botryosphaeriaceae group are shown.

numbers of annotated genes in these categories (Table 3). In grape and pistachio, species in the genera Neofusicoccum and Lasiodiplodia, are typically more virulent than species in the genera Diplodia and Dothiorella (Úrbez-Torres et al., 2008; Úrbez-Torres and Gubler, 2009; Nouri et al., 2019). GH functions of $\beta$-glucosidases, $\beta$-xylosidases, glucanases, $\mathrm{L}$-arabinofuranosidase, and galactanase were present in all the pathogens in this study and significantly more in Neofusicoccum and Lasiodiplodia. In the same way as the GH, AA functions like cellobiose dehydrogenases, alcohol oxidases, pyranose 


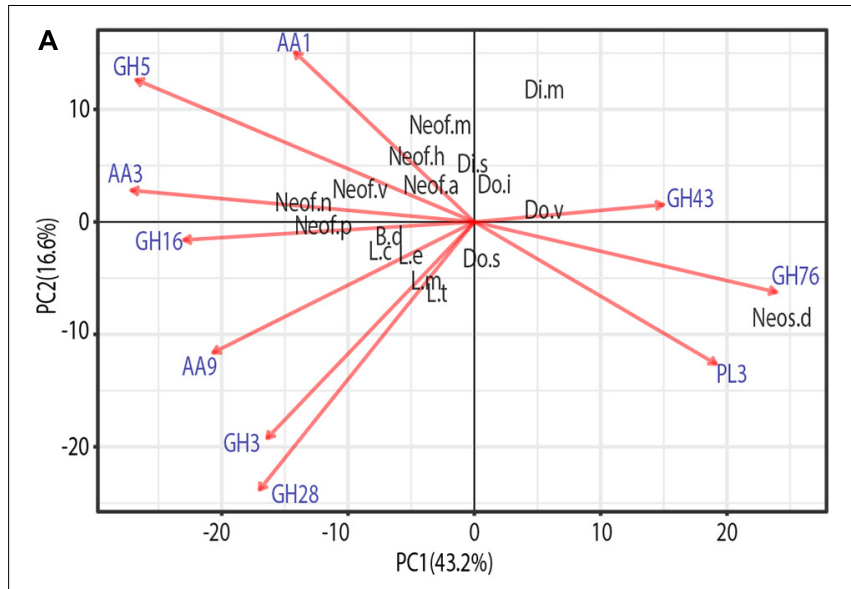

B

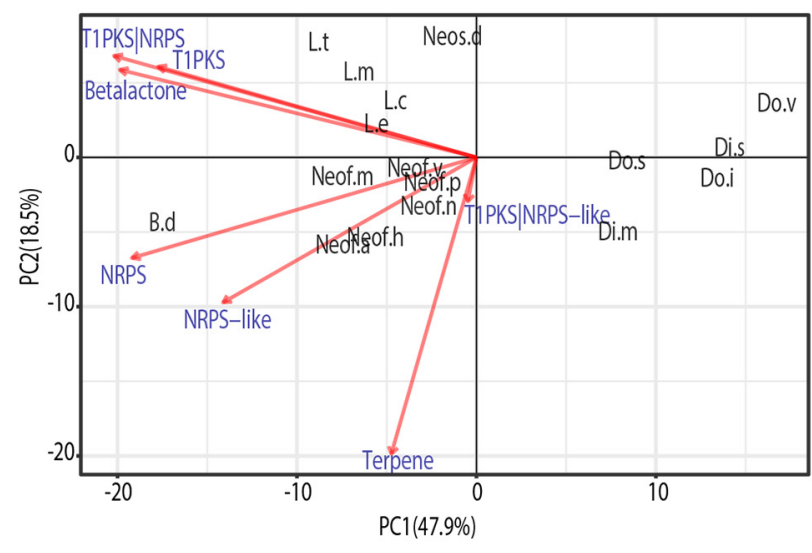

FIGURE 5 | Phylogenetic principal component analysis (PCA) of the expanded gene families grouped by secreted CAZymes (A) and Secondary metabolism clusters (B). Only vectors of the largest loadings are shown.

oxidase were more abundant among Neofusicoccum species and B. dothidea. GH and AA play a critical role in the degradation of the host cell wall compounds (Kubicek et al., 2014), which is involved with the degree of pathogenicity within these genera, albeit on grape, the host we examined. Marsberg et al. (2017); Massonnet et al. (2018), and Félix et al. (2019), found similar numbers of CAZymes in Neof. parvum, L. theobromae, and $B$. dothidea, respectively. P450s are instrumental to the development of all organisms. These enzymes are involved in many aspects of primary and secondary metabolisms and are responsible for xenobiotic detoxification and degradation (Črešnar and Petrič, 2011; Moktali et al., 2012). Virulence may in part reflect the ability of some species to better tolerate and, further, to metabolize phenolic compounds produced by the host. Both Neof. parvum and Di. seriata can eliminate the stilbene piceid and its derivative resveratrol in vitro (Stempien et al., 2017), but the former is better able to tolerate resveratrol derivatives ampelopsin A, hopeaphenol, isohopeaphenol, miyabenol C, and $\varepsilon$-viniferin, which are produced at higher levels in planta in response to Neof. parvum versus Di. seriata infection (Lambert et al., 2012). Therefore, it is not unexpected to see a variable profile amongst genera in the Botryosphaeriaceae family and even within a single genus. As presented in Figure 2, some superfamilies are abundant in Neofusicoccum, Lasiodiplodia and Botryosphaeria genera, but other superfamilies are especially more numerous in the Basidiomycetes species included in this study. On the other hand, for most of the superfamilies presented, Sa. cerevisiae shows a considerable lack of such annotated genes, but CYP53 and CYP578 the counts are comparable with the rest of the species. This variation is sourced by the constant evolution and adaptation of the microorganism and hosts to their specific environment (Yan et al., 2018).

As plants evolve new defense mechanisms and compounds against pathogens, the fungi diversify their methods to degrade these compounds or generate new metabolites to attack their hosts (Deng et al., 2007; Yan et al., 2018). The Botryosphaeriaceae species in this study and the two Basidiomycetes present a set of fungal peroxidases that range from 41 to 62 . As for the previous putative virulence factors, Neofusicoccum, Lasiodiplodia, and Botryosphaeria genera have the most annotated peroxidases, however, in this case, Diplodia also showed a comparable amount. Manganese peroxidase was only found in the two basidiomycetes. This enzyme has a critical role in the degradation of lignocellulose compounds by basidiomycetes (Elisashvili and Kachlishvili, 2009; Liers et al., 2011), therefore it is very common in white-rot fungi such as F. mediterranea and St. hirsutum (Morgenstern et al., 2010; Lee et al., 2015). Ascomycetes that rot wood are characterized as soft-rot fungi, which do not degrade lignin by producing manganese peroxidase, but instead "alter" lignin (to gain access to cellulose and hemicellulose) by producing lignin peroxidases, peroxidases, polyphenol oxidases, and laccases (Goodell et al., 2008). Haloperoxidases also have roles in lignin degradation and toxic compound resistance (Mayer et al., 2001; Hofrichter et al., 2010; Zámocký and Obinger, 2010). The former enzyme was found in higher numbers in the genus Neofusicoccum compared to other genera within the family. The hybrid ascorbate-cytochrome $\mathrm{C}$ peroxidase was overrepresented in the genera Neofusicoccum, Lasiodiplodia, and Botryosphaeria and is associated directly with the detoxification of ROS (Zámocký et al., 2014; Wang et al., 2016; Segal and Wilson, 2018).

The wide array of transporters annotated in this study suggests a high adaptation to toxic compounds, either produced by other microorganisms, the host, or potentially chemical synthesized fungicides (Stergiopoulos et al., 2002). The number of proteins in the Major Facilitator Superfamily (MFS) and Superfamily in Neofusicoccum, Lasiodiplodia, and Botryosphaeria were more numerous than the other Botryosphaeriaceae species. Protein members of the MFS family may have different functions in the influx/efflux of molecules between cells and the exterior environment, and several cases of fungicide resistances have been associated with the overexpression of certain MFS channels (Stergiopoulos et al., 2002; Gulshan and Moye-Rowley, 2007; Dos Santos et al., 2014; Chen et al., 2017). The former genera have been reported to have lower sensitivities to almost full resistance to different synthetic fungicides (Wang et al., 2010; Tennakoon et al., 2019; Li et al., 2020). Similar behavior was observed in Do. sarmentorum, were the ATP-binding Cassette (ABC) is 
highly represented. The $\mathrm{ABC}$ superfamily plays different roles in fungicide resistance, mycelial growth, and overall pathogenicity (Stergiopoulos et al., 2002; Qi et al., 2018). In addition, the array of secondary metabolite gene clusters is more expanded in the Botryosphaeriaceae family than in the Basidiomycetes except for terpene synthase gene clusters. T1PKS, NRPS, and hybrids of T1PKS-NRPS produce toxic polyketides and toxic polypeptides, which kill host cells and leads to disease development (Luini et al., 2010; Andolfi et al., 2011; Morales-Cruz et al., 2015; Pusztahelyi et al., 2015; Blin et al., 2019).

To evaluate the potential differences in virulence within the Botryosphaeriaceae family in more detail, we executed a Computational Analysis of gene Family Evolution (De Bie et al., 2006). By identifying species and gene families with higher rates of gain and loss can help us to better understand the differences in pathogenicity as it relates to the numbers of copies of virulence genes (Hahn et al., 2005; Morales-Cruz et al., 2015). Six hundred and sixty-six gene families of the proteins analyzed in this study have a significantly higher than expected rate of gain/loss. The annotation of putative virulence factors in Neofusicoccum, Lasiodiplodia, and Botryosphaeria shows an average expansion of these gene families, even if some of the species shows a contraction, the overall clade rate is positive. Among those expanded or contracted families there is a set of functions that are overrepresented. The secreted CAZymes seem to be expanding in Neof. hellenicum, Neof. nonquaesitum, B. dothidea, Di. mutila, Do. iberica, and Do. sarmentorum, whereas the Dothiorella species show contractions in some families. However, almost no significant gain/loss of secreted CAZymes appears to be occurring in the genomes of Lasiodiplodia species. The opposite scenario is observed for the P450s, where Lasiodiplodia appears to be actively evolving, showing major expansions in three of the four species in this study. Also, B. dothidea and three Neofusicoccum species (Neof. parvum, Neofusicoccum australe, and Neofusicoccum mediterraneum) show an expansion of these families. On the other side, Neos. dimidiatum, B. dothidea, Do. sarmentorum, L. exigua, and L. missouriana are actively expanding their secondary metabolite gene clusters. Finally, the wide variety of transporters present in fungi, is the result of the positive selection pressure over them. The need of the fungi to adapt to new environments and hosts had selected for multiple mutations that diversifies the transporters functions (Gladieux et al., 2014). The MFS (2.A.1) displays the largest effect of expansion and contraction among all the species. Botryosphaeria dothidea, L. missouriana, L. exigua, and Di. mutila appear to be actively expanding the MFS transporters. However, Neos. dimidiatum, Di. seriata, Neofusicoccum vitifusiforme, Neof. australe, and Neof. mediterraneum are contracting MFS transporters.

Phylo PCAs results support the idea that within the Botryosphaeriaceae family, Neofusicoccum, Lasiodiplodia, and Botryosphaeria genera are the most virulent (Úrbez-Torres et al., 2008; Úrbez-Torres and Gubler, 2009). There was a very clear separation of these species from the Diplodia, Dothiorella, and Neoscytalidium. The secreted CAZymes that cause the clustering of the Neofusicoccum species are usually associated with laccases, cellobiose dehydrogenases, and cellulase activities. These enzymes usually target components of the plant cell wall such as lignin, cellulose, cellobiose (Cameron and Aust, 2001; Zamocky et al., 2006; Fillat et al., 2016; Di Francesco et al., 2020). Among the functions driving the clustering of Lasiodiplodia and Botryosphaeria, the lytic polysaccharide monooxygenases (LPMOs, AA9) are one of the most important. They have a role in the oxidative degradation of various biopolymers such as cellulose and chitin. LPMOs can increase the activity of cellulases highly, and now, they are used in a mixture for the preparation of biofuels (Frommhagen et al., 2018; Labourel et al., 2020). Therefore, this set of enzymes may facilitate the colonization and infection of their hosts. The separation of Neos. dimidiatum from the rest of species is caused by GH78 which includes mannanases, $\alpha$-glucosidase enzymes and the PL3 family of pectate lyases. As Neos. dimidiatum is also known for infecting the fruits and soft tissues of their hosts (Marques et al., 2013; Nouri et al., 2018), this set of enzymes seems to be well developed.

Lasiodiplodia species have a wide array of secondary metabolites. Their profile varies according to the species, isolate, and even the host (Salvatore et al., 2020). These metabolites are often synthesized by clusters of T1PKS, T1PKS/NRPS, and some beta-lactones (Félix et al., 2019; Salvatore et al., 2020), which are some of the major drivers for their clustering in the phylo-PCA (Figure 5). Neofusicoccum, besides the previous gene clusters, also have lamanypenes and NRPS, which drives their clustering in the PCA. Similar results have been presented by Morales-Cruz et al. (2015) and Massonnet et al. (2018). Very little literature is available about the effect of the secondary metabolites of $B$. dothidea on their plant host; however, this fungus is known for its remarkable ability to produce secondary metabolites in vitro (Wang et al., 2018), which recently have been studied for their potential use as commercial antioxidants (Xiao et al., 2014; Druzian et al., 2020; Valente et al., 2020).

Few of the fungi in this study have been characterized in terms of their interactions with wood and individual wood components, their activation of cell-wall degrading enzymes, or their ability to tolerate phenolic compounds. Therefore, it is difficult to connect the pattern of gene family evolution to such aspects of fungal biology, especially in a comparative way among so many species, none of which have all been compared at once on a single host. The pathogenicity test on young, rooted grapevine plants raises some interesting observations. First, L. theobromae, Neof. parvum, and Neof. australe are among the species that induced the most prominent lesions in the plants. These results are consistent with those of Úrbez-Torres and Gubler (2009), who found these species to be highly virulent on grape. This same study found Di. mutila, Di. seriata, Do. iberica, and Do. viticola to be weakly virulent, which is congruent with the results presented by this study. Although most Neofusicoccum species present high numbers of putative virulence factors, the targets for these may be variable within the genus. In this pathogenicity experiment, the isolates of Neof. vitifusiforme, Neof. nonquaesitum, and Neof. hellenicum were isolated from active cankers in walnut and pistachio trees, and even if some of these 
species can develop disease in grapevine, their virulence on Vitis vinifera may not be the same. Finally, the reasons why lesions produced by $B$. dothidea were not significantly different from the control are difficult to assess with certainty, but studies had reported $B$. dothidea to be weakly or moderately pathogenic on grapevine (Úrbez-Torres and Gubler, 2009; Pitt et al., 2013). Some researchers remark that in potted plants after 5-6 weeks of inoculation with $B$. dothidea, the plants were not different compared to the control, whereas the other species in that study showed poor bud development and stunted green shoot growth (Úrbez-Torres and Gubler, 2009). Also, in other studies, this species is presented as endophytic and latent pathogen and they suggest that the environmental conditions can have a significant effect on the development of the disease (Piškur and Jurc, 2011; Marsberg et al., 2017).

\section{DATA AVAILABILITY STATEMENT}

Sequencing data are available at NCBI (BioProject PRJNA673527). Sequencing data of Diplodia seriata and Neof. parvum can be retrieved from NCBI under BioProject PRJNA261773 and PRJNA321421, respectively. All genome assemblies and gene models are publicly available at Zenodo (doi: 10.5281/zenodo.4417445).

\section{REFERENCES}

Abou-Mansour, E., Débieux, J. L., Ramírez-Suero, M., Bénard-Gellon, M., Magnin-Robert, M., Spagnolo, A., et al. (2015). Phytotoxic metabolites from Neofusicoccum parvum, a pathogen of Botryosphaeria dieback of grapevine. Phytochemistry 115, 207-215. doi: 10.1016/j.phytochem.2015. 01.012

Alkan, C., Sajjadian, S., and Eichler, E. E. (2011). Limitations of next-generation genome sequence assembly. Nat. Methods 8, 61-65. doi: 10.1038/nmeth.1527

Alves, A., Crous, P. W., Correia, A., and Phillips, A. J. L. (2008). Morphological and molecular data reveal cryptic speciation in Lasiodiplodia theobromae. Fungal Divers. 28, 1-13.

Andolfi, A., Mugnai, L., Luque, J., Surico, G., Cimmino, A., and Evidente, A. (2011). Phytotoxins produced by fungi associated with grapevine trunk diseases. Toxins 3, 1569-1605. doi: 10.3390/toxins3121569

Armenteros, J. J. A., Tsirigos, K. D., Sønderby, C. K., Petersen, T. N., Winther, O., Brunak, S., et al. (2019). SignalP 5.0 improves signal peptide predictions using deep neural networks. Nat. Biotechnol. 37, 420-423. doi: 10.1038/s41587-0190036-z

Baumgartner, K., Fujiyoshi, P. T., Travadon, R., Castlebury, L. A., Wilcox, W. F., and Rolshausen, P. E. (2013). Characterization of species of Diaporthe from wood cankers of grape in eastern North American vineyards. Plant Dis. 97, 912-920. doi: 10.1094/PDIS-04-12-0357-RE

Bankevich, A., Nurk, S., Antipov, D., Gurevich, A. A., Dvorkin, M., Kulikov, A. S., et al. (2012). SPAdes: a new genome assembly algorithm and its applications to single-cell sequencing. J. Comput. Biol. 19, 455-477. doi: 10.1089/cmb.2012. 0021

Baroncelli, R., Amby, D. B., Zapparata, A., Sarrocco, S., Vannacci, G., Le Floch, G., et al. (2016). Gene family expansions and contractions are associated with host range in plant pathogens of the genus Colletotrichum. BMC Genomics 17:555.

Beimforde, C., Feldberg, K., Nylinder, S., Rikkinen, J., Tuovila, H., Dörfelt, H., et al. (2014). Estimating the Phanerozoic history of the ascomycota lineages: combining fossil and molecular data. Mol. Phylogenet. Evol. 78, 386-398. doi: 10.1016/j.ympev.2014.04.024

Blanco-Ulate, B., Morales-Cruz, A., Amrine, K. C., Labavitch, J. M., Powell, A. L., and Cantu, D. (2014). Genome-wide transcriptional profiling of Botrytis cinerea

\section{AUTHOR CONTRIBUTIONS}

RT, KB, DL, and DC conceived the study. DL and RT carried out the pathogenicity experiments. $\mathrm{PR}$ and $\mathrm{RH}-\mathrm{M}$ contributed to fungal strains. JG, AM-C, AM, DL, and DC carried out the computational analysis. JG, DL, KB, and DC wrote the manuscript. All authors read and approved the final manuscript.

\section{FUNDING}

This work was supported by the USDA, National Institute of Food and Agriculture, Specialty Crop Research Initiative (grant 2012-51181-19954) and by the American Vineyard Foundation (grant 1798). DC was also partially supported by the Louis P. Martini Endowment in Viticulture and the UC Davis Chancellor's Fellow Award.

\section{SUPPLEMENTARY MATERIAL}

The Supplementary Material for this article can be found online at: https://www.frontiersin.org/articles/10.3389/fmicb. 2021.652802/full\#supplementary-material

genes targeting plant cell walls during infections of different hosts. Front. Plant Sci. 5:435

Blin, K., Shaw, S., Steinke, K., Villebro, R., Ziemert, N., Lee, S. Y., et al. (2019). AntiSMASH 5.0: updates to the secondary metabolite genome mining pipeline. Nucleic Acids Res. 47, W81-W87.

Bolger, A. M., Lohse, M., and Usadel, B. (2014). Trimmomatic: a flexible trimmer for Illumina sequence data. Bioinformatics 30, 2114-2120. doi: 10.1093/ bioinformatics/btu170

Bouckaert, R., Heled, J., Kühnert, D., Vaughan, T., Wu, C. H., Xie, D., et al. (2014). BEAST 2: a software platform for Bayesian evolutionary analysis. PLoS Comput. Biol. 10:e1003537.

Brakhage, A. A. (2013). Regulation of fungal secondary metabolism. Nat. Rev. Microbiol. 11, 21-32. doi: 10.1038/nrmicro2916

Burgess, T. I., Tan, Y. P., Garnas, J., Edwards, J., Scarlett, K. A., Shuttleworth, L. A., et al. (2019). Current status of the Botryosphaeriaceae in Australia. Austr. Plant Pathol. 48, 35-44. doi: 10.1007/s13313-018-0577-5

Cairns, J. R. K., and Esen, A. (2010). B-Glucosidases. Cell. Mol. Life Sci. 67, 3389-3405.

Cameron, M. D., and Aust, S. D. (2001). Cellobiose dehydrogenase-an extracellular fungal flavocytochrome. Enzyme Microb. Technol. 28, 129-138. doi: 10.1016/ s0141-0229(00)00307-0

Cantarel, B. L., Coutinho, P. M., Rancurel, C., Bernard, T., Lombard, V., and Henrissat, B. (2009). The carbohydrate-active enzymes database (CAZy): an expert resource for glycogenomics. Nucleic Acids Res. 37(Suppl._1), D233D238.

Castresana, J. (2000). Selection of conserved blocks from multiple alignments for their use in phylogenetic analysis. Mol. Biol. Evol. 17, 540-552. doi: 10.1093/ oxfordjournals.molbev.a026334

Chacón, J. L., Gramaje, D., Izquierdo, P. M., Martínez, J., and Mena, A. (2020). Evaluation of six red grapevine cultivars inoculated with Neofusicoccum parvum. Eur. J. Plant Pathol. 158, 811-815. doi: 10.1007/s10658-020-02 111-9

Chen, L. H., Tsai, H. C., Yu, P. L., and Chung, K. R. (2017). A major facilitator superfamily transporter-mediated resistance to oxidative stress and fungicides requires Yap1, Skn7, and MAP kinases in the citrus fungal pathogen Alternaria alternata. PLoS One 12:e0169103. doi: 10.1371/journal.pone.0169103 
Chen, S., Morgan, D. P., Hasey, J. K., Anderson, K., and Michailides, T. J. (2014). Phylogeny, morphology, distribution, and pathogenicity of Botryosphaeriaceae and Diaporthaceae from English walnut in California. Plant Dis. 98, 636-652. doi: 10.1094/pdis-07-13-0706-re

Chen, W., Lee, M. K., Jefcoate, C., Kim, S. C., Chen, F., and Yu, J. H. (2014). Fungal cytochrome P450 monooxygenases: their distribution, structure, functions, family expansion, and evolutionary origin. Genome Biol. Evol. 6, 1620-1634. doi: $10.1093 /$ gbe/evu132

Choi, J., Détry, N., Kim, K. T., Asiegbu, F. O., Valkonen, J. P., and Lee, Y. H. (2014). fPoxDB: fungal peroxidase database for comparative genomics. BMC Microbiol. 14:117. doi: 10.1186/1471-2180-14-117

Conesa, A., Götz, S., García-Gómez, J. M., Terol, J., Talón, M., and Robles, M. (2005). Blast2GO: a universal tool for annotation, visualization and analysis in functional genomics research. Bioinformatics 21, 3674-3676. doi: 10.1093/ bioinformatics/bti610

Črešnar, B., and Petrič, Š (2011). Cytochrome P450 enzymes in the fungal kingdom. Biochimica et Biophysica Acta (BBA)-Proteins Proteomics 1814, 29-35. doi: 10. 1016/j.bbapap.2010.06.020

Crous, P. W., Slippers, B., Wingfield, M. J., Rheeder, J., Marasas, W. F., Philips, A. J., et al. (2006). Phylogenetic lineages in the Botryosphaeriaceae. Stud. Mycol. 55, 235-253. doi: 10.3114/sim.55.1.235

Daniel, G., Volc, J., and Kubatova, E. (1994). Pyranose oxidase, a major source of $\mathrm{H} 2 \mathrm{O} 2$ during wood degradation by Phanerochaete chrysosporium, Trametes versicolor, and Oudemansiella mucida. Appl. Environ. Microbiol. 60, 2524-2532. doi: 10.1128/aem.60.7.2524-2532.1994

De Bie, T., Cristianini, N., Demuth, J. P., and Hahn, M. W. (2006). CAFE: a computational tool for the study of gene family evolution. Bioinformatics 22, 1269-1271. doi: 10.1093/bioinformatics/btl097

Del Sorbo, G., Schoonbeek, H. J., and De Waard, M. A. (2000). Fungal transporters involved in efflux of natural toxic compounds and fungicides. Fungal Genet. Biol. 30, 1-15. doi: 10.1006/fgbi.2000.1206

Deng, J., Carbone, I., and Dean, R. A. (2007). The evolutionary history of cytochrome P450 genes in four filamentous Ascomycetes. BMC Evol. Biol. 7:30. doi: $10.1186 / 1471-2148-7-30$

Denny, T. P., and VanEtten, H. D. (1983). Tolerance of Nectria haematococca MP VI to the phytoalexin pisatin in the absence of detoxification. Microbiology 129, 2893-2901. doi: 10.1099/00221287-129-9-2893

Denny, T. P., Matthews, P. S., and VanEtten, H. D. (1987). A possible mechanism of nondegradative tolerance of pisatin in Nectria haematococca MP VI. Physiol. Mol. Plant Pathol. 30, 93-107. doi: 10.1016/0885-5765(87)90085-3

Desprez-Loustau, M. L., Marçais, B., Nageleisen, L. M., Piou, D., and Vannini, A. (2006). Interactive effects of drought and pathogens in forest trees. Ann. For. Sci. 63, 597-612. doi: 10.1051/forest:2006040

Di Francesco, A., Rusin, C., Di Foggia, M., Marceddu, S., Rombolà, A., Botelho, R. V., et al. (2020). Characterization of apple cultivar susceptibility to Neofusicoccum parvum Brazilian strains. Eur. J. Plant Pathol. 156, 939-951. doi: 10.1007/s10658-020-01945-7

Dos Santos, S. C., Teixeira, M. C., Dias, P. J., and Sá-Correia, I. (2014). MFS transporters required for multidrug/multixenobiotic (MD/MX) resistance in the model yeast: understanding their physiological function through postgenomic approaches. Front. Physiol. 5:180.

Druzian, S. P., Pinheiro, L. N., Susin, N. M. B., Dal Prá, V., Mazutti, M. A., Kuhn, R. C., et al. (2020). Production of metabolites with antioxidant activity by Botryosphaeria dothidea in submerged fermentation. Bioprocess Biosyst. Eng. 43, 13-20. doi: 10.1007/s00449-019-02200-y

Edgar, R. C. (2004). MUSCLE: multiple sequence alignment with high accuracy and high throughput. Nucleic Acids Res. 32, 1792-1797. doi: 10.1093/nar/gkh340

Elisashvili, V., and Kachlishvili, E. (2009). Physiological regulation of laccase and manganese peroxidase production by white-rot Basidiomycetes. J. Biotechnol. 144, 37-42. doi: 10.1016/j.jbiotec.2009.06.020

Enright, A. J., Van Dongen, S., and Ouzounis, C. A. (2002). An efficient algorithm for large-scale detection of protein families. Nucleic Acids Res. 30, 1575-1584. doi: $10.1093 /$ nar/30.7.1575

Faure, D. (2002). The family-3 glycoside hydrolases: from housekeeping functions to host-microbe interactions. Appl. Environ. Microbiol. 68, 1485-1490. doi: 10.1128/aem.68.4.1485-1490.2002

Félix, C., Meneses, R., Gonçalves, M. F., Tilleman, L., Duarte, A. S., Jorrín-Novo, J. V., et al. (2019). A multi-omics analysis of the grapevine pathogen
Lasiodiplodia theobromae reveals that temperature affects the expression of virulence-and pathogenicity-related genes. Sci. Rep. 9:13144.

Fillat, Ú, Martín-Sampedro, R., Macaya-Sanz, D., Martín, J. A., Ibarra, D., Martínez, M. J., et al. (2016). Screening of eucalyptus wood endophytes for laccase activity. Process Biochem. 51, 589-598. doi: 10.1016/j.procbio.2016.02.006

Finn, R. D., Coggill, P., Eberhardt, R. Y., Eddy, S. R., Mistry, J., Mitchell, A. L., et al. (2016). The Pfam protein families database: towards a more sustainable future. Nucleic Acids Res. 44, D279-D285.

Fischer, M. (2006). Biodiversity and geographic distribution of basidiomycetes causing esca-associated white rot in grapevine: a worldwide perspective. Phytopathol. Mediterranea 45, S30-S42.

Fischer, M., Knoll, M., Sirim, D., Wagner, F., Funke, S., and Pleiss, J. (2007). The Cytochrome P450 engineering database: a navigation and prediction tool for the cytochrome P450 protein family. Bioinformatics 23, 2015-2017. doi: 10.1093/bioinformatics/btm268

Floudas, D., Binder, M., Riley, R., Barry, K., Blanchette, R. A., Henrissat, B., et al. (2012). The Paleozoic origin of enzymatic lignin decomposition reconstructed from 31 fungal genomes. Science 336, 1715-1719.

Frommhagen, M., Westphal, A. H., Van Berkel, W. J., and Kabel, M. A. (2018). Distinct substrate specificities and electron-donating systems of fungal lytic polysaccharide monooxygenases. Front. Microbiol. 9:1080.

Galarneau, E. R., Lawrence, D. P., Travadon, R., and Baumgartner, K. (2019). Drought exacerbates botryosphaeria dieback symptoms in grapevines and confounds host-based molecular markers of infection by Neofusicoccum parvum. Plant Dis. 103, 1738-1745. doi: 10.1094/pdis-09-18-1549-re

Gladieux, P., Ropars, J., Badouin, H., Branca, A., Aguileta, G., De Vienne, D. M., et al. (2014). Fungal evolutionary genomics provides insight into the mechanisms of adaptive divergence in eukaryotes. Mol. Ecol. 23, 753-773. doi: 10.1111/mec.12631

Goodell, B., Qian, Y., and Jellison, J. (2008). Fungal decay of wood: soft rot-brown rot-white rot. ACS Symp. Ser. 9-31. doi: 10.1021/bk-2008-0982.ch002

Gramaje, D., Agustí-Brisach, C., Pérez-Sierra, A., Moralejo, E., Olmo, D., Mostert, L. I. Z. E. L., et al. (2012). Fungal trunk pathogens associated with wood decay of almond trees on Mallorca (Spain). Persoonia 28, 1-13. doi: 10.3767/ $003158512 \times 626155$

Guan, X., Essakhi, S., Laloue, H., Nick, P., Bertsch, C., and Chong, J. (2016). Mining new resources for grape resistance against Botryosphaeriaceae: a focus on Vitis vinifera subsp. sylvestris. Plant Pathol. 65, 273-284. doi: 10.1111/ppa. 12405

Guindon, S., Dufayard, J. F., Lefort, V., Anisimova, M., Hordijk, W., and Gascuel, O. (2010). New algorithms and methods to estimate maximum-likelihood phylogenies: assessing the performance of PhyML 3.0. Syst. Biol. 59, 307-321. doi: $10.1093 /$ sysbio/syq010

Gulshan, K., and Moye-Rowley, W. S. (2007). Multidrug resistance in fungi. Eukaryot. Cell 6, 1933-1942. doi: 10.1128/ec.00254-07

Guo, M., Guo, W., Chen, Y., Dong, S., Zhang, X., Zhang, H., et al. (2010). The basic leucine zipper transcription factor Moatf1 mediates oxidative stress responses and is necessary for full virulence of the rice blast fungus Magnaporthe oryzae. Mol. Plant Microbe Interact. 23, 1053-1068. doi: 10.1094/mpmi-238-1053

Hahn, M. W., De Bie, T., Stajich, J. E., Nguyen, C., and Cristianini, N. (2005). Estimating the tempo and mode of gene family evolution from comparative genomic data. Genome Res. 15, 1153-1160. doi: 10.1101/gr.35 67505

Harreither, W., Sygmund, C., Augustin, M., Narciso, M., Rabinovich, M. L., Gorton, L., et al. (2011). Catalytic properties and classification of cellobiose dehydrogenases from ascomycetes. Appl. Environ. Microbiol. 77, 1804-1815. doi: 10.1128/aem.02052-10

Henriksson, G., Johansson, G., and Pettersson, G. (2000). A critical review of cellobiose dehydrogenases. J. Biotechnol. 78, 93-113. doi: 10.1016/s01681656(00)00206-6

Hernández-Ortega, A., Ferreira, P., and Martínez, A. T. (2012). Fungal aryl-alcohol oxidase: a peroxide-producing flavoenzyme involved in lignin degradation. Appl. Microbiol. Biotechnol. 93, 1395-1410. doi: 10.1007/s00253-0113836-8

Hofrichter, M., Ullrich, R., Pecyna, M. J., Liers, C., and Lundell, T. (2010). New and classic families of secreted fungal heme peroxidases. Appl. Microbiol. Biotechnol. 87, 871-897. doi: 10.1007/s00253-010-2633-0 
Holland, L. A., Trouillas, F. P., Nouri, M. T., Lawrence, D. P., Crespo, M., Doll, D. A., et al. (2020). Fungal pathogens associated with canker diseases of almond in california. Plant Dis. 105, 346-360. doi: 10.1094/pdis-10-19-2128-re

Hrycan, J., Hart, M., Bowen, P., Forge, T., and Úrbez-Torres, J. R. (2020). Grapevine trunk disease fungi: their roles as latent pathogens and stress factors that favour disease development and symptom expression. Phytopathologia Mediterranea 59, 395-424.

Inderbitzin, P., Bostock, R. M., Trouillas, F. P., and Michailides, T. J. (2010). A six locus phylogeny reveals high species diversity in Botryosphaeriaceae from California almond. Mycologia 102, 1350-1368. doi: 10.3852/10-006

Inkscape Project (2020). Inkscape. Available online at: from https://inkscape.org (accessed July 15, 2020).

Jones, L., Riaz, S., Morales-Cruz, A., Amrine, K. C., McGuire, B., Gubler, W. D., et al. (2014). Adaptive genomic structural variation in the grape powdery mildew pathogen, Erysiphe necator. BMC Genomics 15:1081. doi: 10.1186/ 1471-2164-15-1081

Keller, N. P. (2019). Fungal secondary metabolism: regulation, function and drug discovery. Nat. Rev. Microbiol. 17, 167-180. doi: 10.1038/s41579-0180121-1

Knob, A., Terrasan, C. F., and Carmona, E. C. (2010). $\beta$-Xylosidases from filamentous fungi: an overview. World J Microbiol. Biotechnol. 26, 389-407. doi: 10.1007/s11274-009-0190-4

Kubicek, C. P., Starr, T. L., and Glass, N. L. (2014). Plant cell wall-degrading enzymes and their secretion in plant-pathogenic fungi. Annu. Rev. Phytopathol. 52, 427-451. doi: 10.1146/annurev-phyto-102313-045831

Labourel, A., Frandsen, K. E., Zhang, F., Brouilly, N., Grisel, S., Haon, M., et al. (2020). A fungal family of lytic polysaccharide monooxygenase-like copper proteins. Nat. Chem. Biol. 16, 345-350. doi: 10.1038/s41589-019-0438-8

Lambert, C., Bisson, J., Waffo-Téguo, P., Papastamoulis, Y., Richard, T., CorioCostet, M. F., et al. (2012). Phenolics and their antifungal role in grapevine wood decay: focus on the Botryosphaeriaceae family. J. Agric. Food Chem. 60, 11859-11868. doi: $10.1021 /$ jf $303290 \mathrm{~g}$

Lawrence, D. P., Hand, F. P., Gubler, W. D., and Trouillas, F. P. (2017). Botryosphaeriaceae species associated with dieback and canker disease of bay laurel in northern California with the description of Dothiorella californica sp. nov. Fungal Biol. 121, 347-360. doi: 10.1016/j.funbio.2016.09.005

Lawrence, D. P., Travadon, R., and Baumgartner, K. (2018). Novel seimatosporium species from grapevine in northern California and their interactions with fungal pathogens involved in the trunk-disease complex. Plant Dis. 102, 1081-1092. doi: 10.1094/pdis-08-17-1247-re

Lee, S. Y., Kim, S. H., Hong, C. Y., Kim, H. Y., Ryu, S. H., and Choi, I. G. (2015). Biotransformation of (-)- $\alpha$-pinene by whole cells of white rot fungi, Ceriporia sp. ZLY-2010 and Stereum hirsutum. Mycobiology 43, 297-302. doi: 10.5941/myco.2015.43.3.297

Li, Y., Tsuji, S. S., Hu, M., Câmara, M. P. S., Michereff, S. J., Schnabel, G., et al. (2020). Characterization of difenoconazole resistance in Lasiodiplodia theobromae from papaya in Brazil. Pest. Manag. Sci. 76, 1344-1352. doi: 10. $1002 /$ ps.5645

Liers, C., Arnstadt, T., Ullrich, R., and Hofrichter, M. (2011). Patterns of lignin degradation and oxidative enzyme secretion by different wood-and littercolonizing basidiomycetes and ascomycetes grown on beech-wood. FEMS Microbiol. Ecol. 78, 91-102. doi: 10.1111/j.1574-6941.2011.01144.x

Linaldeddu, B. T., Deidda, A., Scanu, B., Franceschini, A., Serra, S., BerrafTebbal, A., et al. (2015). Diversity of Botryosphaeriaceae species associated with grapevine and other woody hosts in Italy, Algeria and Tunisia, with descriptions of Lasiodiplodia exigua and Lasiodiplodia mediterranea sp. nov. Fungal Divers. 71, 201-214. doi: 10.1007/s13225-014-0301-x

Lo Presti, L., Lanver, D., Schweizer, G., Tanaka, S., Liang, L., Tollot, M., et al. (2015). Fungal effectors and plant susceptibility. Annu. Rev. Plant Biol. 66, 513-545. doi: 10.1146/annurev-arplant-043014-114623

Lombard, V., Golaconda Ramulu, H., Drula, E., Coutinho, P. M., and Henrissat, B. (2014). The carbohydrate-active enzymes database (CAZy) in 2013. Nucleic Acids Res. 42, D490-D495.

Luini, E., Fleurat-Lessard, P., Rousseau, L., Roblin, G., and Berjeaud, J. M. (2010). Inhibitory effects of polypeptides secreted by the grapevine pathogens Phaeomoniella chlamydospora and Phaeoacremonium aleophilum on plant cell activities. Physiol. Mol. Plant Pathol. 74, 403-411. doi: 10.1016/j.pmpp.2010. 06.007
Luo, Y., Lichtemberg, P. S. F., Niederholzer, F. J. A., Lightle, D. M., Felts, D. G., and Michailides, T. J. (2019). Understanding the process of latent infection of canker-causing pathogens in stone fruit and nut crops in California. Plant Dis. 103, 2374-2384. doi: 10.1094/pdis-11-18-1963-re

Luque, J., Martos, S., and Garcia-Figueres, F. (2010). Effects of water stress and inoculation with Eutypa lata and Neofusicoccum parvum on young grapevine plants. Phytopathologia Mediterranea 49:120.

Ma, Z., Boehm, E. W., Luo, Y., and Michailides, T. J. (2001). Population structure of Botryosphaeria dothidea from pistachio and other hosts in California. Phytopathology 91, 665-672. doi: 10.1094/PHYTO.2001.91.7.665

Marques, M. W., Lima, N. B., de Morais, M. A., Michereff, S. J., Phillips, A. J., and Câmara, M. P. (2013). Botryosphaeria, Neofusicoccum, Neoscytalidium and Pseudofusicoccum species associated with mango in Brazil. Fungal Divers. 61, 195-208. doi: 10.1007/s13225-013-0258-1

Marsberg, A., Kemler, M., Jami, F., Nagel, J. H., Postma-Smidt, A., Naidoo, S., et al. (2017). Botryosphaeria dothidea: a latent pathogen of global importance to woody plant health. Mol. Plant Pathol. 18, 477-488. doi: 10.1111/mpp.12495

Martínková, L., Kotik, M., Marková, E., and Homolka, L. (2016). Biodegradation of phenolic compounds by Basidiomycota and its phenol oxidases: a review. Chemosphere 149, 373-382. doi: 10.1016/j.chemosphere.2016.01.022

Massonnet, M., Morales-Cruz, A., Figueroa-Balderas, R., Lawrence, D. P., Baumgartner, K., and Cantu, D. (2018). Condition-dependent co-regulation of genomic clusters of virulence factors in the grapevine trunk pathogen Neofusicoccum parvum. Mol. Plant Pathol. 19, 21-34. doi: 10.1111/mpp.12491

Mayer, A. M. (2006). Polyphenol oxidases in plants and fungi: going places? a review. Phytochemistry 67, 2318-2331. doi: 10.1016/j.phytochem.2006.08.006

Mayer, A. M., Staples, R. C., and Gil-ad, N. L. (2001). Mechanisms of survival of necrotrophic fungal plant pathogens in hosts expressing the hypersensitive response. Phytochemistry 58, 33-41. doi: 10.1016/s0031-9422(01)00187-x

McDonald, V., Lynch, S., and Eskalen, A. (2009). First report of Neofusicoccum australe, N. luteum, and N. parvum associated with avocado branch canker in California. Plant Dis. 93:967. doi: 10.1094/pdis-93-9-0967b

Michailides, T. J. (1991). Pathogenicity, distribution, sources of inoculum, and infection courts of Botryosphaeria dothidea on pistachio. Phytopathology 81, 566-573. doi: 10.1094/phyto-81-566

Moktali, V., Park, J., Fedorova-Abrams, N. D., Park, B., Choi, J., Lee, Y. H., et al. (2012). Systematic and searchable classification of cytochrome P450 proteins encoded by fungal and oomycete genomes. BMC Genomics 13:525. doi: 10. 1186/1471-2164-13-525

Molina, L., and Kahmann, R. (2007). An Ustilago maydis gene involved in $\mathrm{H} 2 \mathrm{O} 2$ detoxification is required for virulence. Plant Cell 19, 2293-2309. doi: 10.1105/ tpc. 107.052332

Morales-Cruz, A., Allenbeck, G., Figueroa-Balderas, R., Ashworth, V. E., Lawrence, D. P., Travadon, R., et al. (2018). Closed-reference metatranscriptomics enables in planta profiling of putative virulence activities in the grapevine trunk disease complex. Mol. Plant Pathol. 19, 490-503. doi: 10.1111/mpp.12544

Morales-Cruz, A., Amrine, K. C., Blanco-Ulate, B., Lawrence, D. P., Travadon, R., Rolshausen, P. E., et al. (2015). Distinctive expansion of gene families associated with plant cell wall degradation, secondary metabolism, and nutrient uptake in the genomes of grapevine trunk pathogens. BMC Genomics 16:469. doi: 10.1094/pdis-05-13-0523-re

Morgenstern, I., Robertson, D. L., and Hibbett, D. S. (2010). Characterization of three mnp genes of Fomitiporia mediterranea and report of additional class II peroxidases in the order Hymenochaetales. Appl. Environ. Microbiol. 76, 6431-6440. doi: 10.1128/aem.00547-10

Mullen, J. M., Gilliam, C. H., Hagan, A. K., and Morgan-Jones, G. (1991). Canker of dogwood caused by Lasiodiplodia theobromae, a disease influenced by drought stress or cultivar selection. Plant Dis. 75, 886-889. doi: 10.1094/pd-750886

Nouri, M. T., Lawrence, D. P., Holland, L. A., Doll, D. A., Kallsen, C. E., Culumber, C. M., et al. (2019). Identification and pathogenicity of fungal species associated with canker diseases of pistachio in California. Plant Dis. 103, 2397-2411. doi: 10.1094/pdis-10-18-1717-re

Nouri, M. T., Lawrence, D. P., Yaghmour, M. A., Michailides, T. J., and Trouillas, F. P. (2018). Neoscytalidium dimidiatum causing canker, shoot blight and fruit rot of almond in California. Plant Dis. 102, 1638-1647. doi: 10.1094/pdis-1217-1967-re

Ohno, S. (2013). Evolution by Gene Duplication. Berlin: Springer. 
Old, K. M., Gibbs, R., Craig, I., Myers, B. J., and Yuan, Z. Q. (1990). Effect of drought and defoliation on the susceptibility of Eucalyptus to cankers caused by Endothia gyrosa and Botryosphaeria ribis. Aust. J. Bot. 38, 571-581. doi: 10.1071/bt9900571

Parra, G., Bradnam, K., and Korf, I. (2007). CEGMA: a pipeline to accurately annotate core genes in eukaryotic genomes. Bioinformatics 23, 1061-1067. doi: 10.1093/bioinformatics/btm071

Perlin, M. H., Andrews, J., and San Toh, S. (2014). Essential letters in the fungal alphabet: $\mathrm{ABC}$ and MFS transporters and their roles in survival and pathogenicity Adv. Genet. 85, 201-253. doi: 10.1016/b978-0-12-800271-1. 00004-4

Petrini, O., and Fisher, P. J. (1988). A comparative study of fungal endophytes in xylem and whole stem of Pinus sylvestris and Fagus sylvatica. Trans. Br. Mycol. Soc. 91, 233-238. doi: 10.1016/s0007-1536(88)80210-9

Peyraud, R., Mbengue, M., Barbacci, A., and Raffaele, S. (2019). Intercellular cooperation in a fungal plant pathogen facilitates host colonization. Proc. Natl. Acad. Sci. U.S.A. 116, 3193-3201. doi: 10.1073/pnas.1811267116

Phillips, A. J. L., Alves, A., Pennycook, S. R., Johnston, P. R., Ramaley, A., Akulov, A., et al. (2008). Resolving the phylogenetic and taxonomic status of darkspored teleomorph genera in the Botryosphaeriaceae. Persoonia 21, 29-55. doi: 10.3767/003158508x340742

Phillips, A. J. L., Lopes, J., Abdollahzadeh, J., Bobev, S., and Alves, A. (2012). Resolving the Diplodia complex on apple and other Rosaceae hosts. Persoonia 29, 29-38. doi: 10.3767/003158512x658899

Phillips, A., Alves, A., Correia, A., and Luque, J. (2005). Two new species of Botryosphaeria with brown, 1-septate ascospores and Dothiorella anamorphs. Mycologia 97, 513-529. doi: 10.3852/mycologia.97.2.513

Piškur, B., and Jurc, D. (2011). Unusual weather conditions as triggers of pathogenic activities of endophytic fungi-Botryosphaeria dothidea as an example. Zbornik Predavanj in Referatov, 10. Slovenskega Posvetovanja o Varstvu Rastlin, Podčetrtek, Slovenia. 241-245. Available online at: https://www. cabdirect.org/cabdirect/abstract/20143268096

Pitt, W. M., Huang, R., Steel, C. C., and Savocchia, S. (2013). Pathogenicity and epidemiology of Botryosphaeriaceae species isolated from grapevines in Australia. Aust. Plant Pathol. 42, 573-582. doi: 10.1007/s13313-013-0221-3

Polizeli, M. L. T. M., Rizzatti, A. C. S., Monti, R., Terenzi, H. F., Jorge, J. A., and Amorim, D. S. (2005). Xylanases from fungi: properties and industrial applications. Appl. Microbiol. Biotechnol. 67, 577-591. doi: 10.1007/s00253005-1904-7

Powell, A. J., Conant, G. C., Brown, D. E., Carbone, I., and Dean, R. A. (2008). Altered patterns of gene duplication and differential gene gain and loss in fungal pathogens. BMC Genomics 9:147. doi: 10.1186/1471-2164-9-147

Pusey, P. L. (1989). Influence of water stress on susceptibility of nonwounded peach bark to Botryosphaeria dothidea. Plant Dis. 73, 1000-1003. doi: 10.1094/pd-731000

Pusztahelyi, T., Holb, I. J., and Pócsi, I. (2015). Secondary metabolites in fungusplant interactions. Front. Plant Sci. 6:573.

Qi, P. F., Zhang, Y. Z., Liu, C. H., Zhu, J., Chen, Q., Guo, Z. R., et al. (2018). Fusarium graminearum ATP-binding cassette transporter gene FgABCC9 is required for its transportation of salicylic acid, fungicide resistance, mycelial growth and pathogenicity towards wheat. Int. J. Mol. Sci. 19:2351. doi: 10.3390/ ijms 19082351

Rambaut, A. (2012). Figtree 1.4.0. Avaliable online at: http://tree.bio.ed.ac.uk/ software/figtree/ (accessed August 8, 2020).

Revell, L. J. (2012). phytools: an R package for phylogenetic comparative biology (and other things). Methods Ecol. Evol. 3, 217-223. doi: 10.1111/j.2041-210x. 2011.00169.x

Revell, L. J., and Collar, D. C. (2009). Phylogenetic analysis of the evolutionary correlation using likelihood. Evol. Int. J. Organ. Evol. 63, 1090-1100. doi: 10.1111/j.1558-5646.2009.00616.x

Saier, M. H., Reddy, V. S., Tsu, B. V., Ahmed, M. S., Li, C., and Moreno-Hagelsieb, G. (2016). The transporter classification database (TCDB): recent advances. Nucleic Acids Res. 44, D372-D379.

Saier, M. H., Tran, C. V., and Barabote, R. D. (2006). TCDB: the transporter classification database for membrane transport protein analyses and information. Nucleic Acids Res. 34, D181-D186.
Salvatore, M. M., Alves, A., and Andolfi, A. (2020). Secondary metabolites of Lasiodiplodia theobromae: distribution, chemical diversity, bioactivity, and implications of their occurrence. Toxins 12:457. doi: 10.3390/toxins12070457

Sampedro, J., Valdivia, E. R., Fraga, P., Iglesias, N., Revilla, G., and Zarra, I. (2017). Soluble and membrane-bound $\beta$-glucosidases are involved in trimming the xyloglucan backbone. Plant Physiol. 173, 1017-1030. doi: 10.1104/pp.16.01713

Schulze-Lefert, P., and Panstruga, R. (2011). A molecular evolutionary concept connecting nonhost resistance, pathogen host range, and pathogen speciation. Trends Plant Sci. 16, 117-125. doi: 10.1016/j.tplants.2011.01.001

Segal, L. M., and Wilson, R. A. (2018). Reactive oxygen species metabolism and plant-fungal interactions. Fungal Genet. Biol. 110, 1-9. doi: 10.1016/j.fgb.2017. 12.003

Seifert, K. A., Crous, P. W., Gams, W., and Samuels, G. J. (2000). Molecules, morphology and classification: towards monophyletic genera in the Ascomycetes. Stud. Mycol. 56, 1-4.

Simão, F. A., Waterhouse, R. M., Ioannidis, P., Kriventseva, E. V., and Zdobnov, E. M. (2015). BUSCO: assessing genome assembly and annotation completeness with single-copy orthologs. Bioinformatics 31, 3210-3212. doi: 10.1093/ bioinformatics/btv351

Sivanesan, A. (1984). The Bitunicate Ascomycetes and Their Anamorphs. Vaduz: Lubrecht \& Cramer Ltd.

Slippers, B., and Wingfield, M. J. (2007). Botryosphaeriaceae as endophytes and latent pathogens of woody plants: diversity, ecology and impact. Fungal Biol. Rev. 21, 90-106. doi: 10.1016/j.fbr.2007.06.002

Slippers, B., Burgess, T., Pavlic, D., Ahumada, R., Maleme, H., Mohali, S., et al. (2009). A diverse assemblage of Botryosphaeriaceae infect eucalyptus in native and non-native environments. S. For. J. For. Sci. 71, 101-110. doi: 10.2989/sf. 2009.71.2.3.818

Slippers, B., Smit, W. A., Crous, P. W., Coutinho, T. A., Wingfield, B. D., and Wingfield, M. J. (2007). Taxonomy, phylogeny and identification of Botryosphaeriaceae associated with pome and stone fruit trees in South Africa and other regions of the world. Plant Pathol. 56, 128-139.

Smit, A., Hubley, R., and Green, P. (1996-2015). RepeatMasker Open-3.0. Available online at: http://www.repeatmasker.org (accessed November 6, 2016).

Smith, H., Kemp, G. H. J., and Wingfield, M. J. (1994). Canker and die-back of eucalyptus in South Africa caused by Botryosphaeria dothidea. Plant Pathol. 43, 1031-1034. doi: 10.1111/j.1365-3059.1994.tb01653.x

Stanke, M., Keller, O., Gunduz, I., Hayes, A., Waack, S., and Morgenstern, B. (2006). AUGUSTUS: ab initio prediction of alternative transcripts. Nucleic Acids Res. 34(Suppl._2), W435-W439.

Stempien, E., Goddard, M. L., Wilhelm, K., Tarnus, C., Bertsch, C., and Chong, J. (2017). Grapevine Botryosphaeria dieback fungi have specific aggressiveness factor repertory involved in wood decay and stilbene metabolization. PLoS One 20:e0188766. doi: 10.1371/journal.pone.0188766

Stergiopoulos, I., Zwiers, L. H., and De Waard, M. A. (2002). Secretion of natural and synthetic toxic compounds from filamentous fungi by membrane transporters of the ATP-binding cassette and major facilitator superfamily. Eur. J. Plant Pathol. 108, 719-734. doi: 10.1007/978-94-010-0001-7_16

Suzuki, H., MacDonald, J., Syed, K., Salamov, A., Hori, C., Aerts, A., et al. (2012). Comparative genomics of the white-rot fungi, Phanerochaete carnosa and P. chrysosporium, to elucidate the genetic basis of the distinct wood types they colonize. BMC Genomics 13:444. doi: 10.1186/1471-2164-13-444

Tennakoon, K. M. S., Ridgway, H. J., Jaspers, M. V., Langford, G., and Jones, E. E. (2019). Evaluation of fungicide efficacy against Neofusicoccum species causing dieback disease of blueberries in New Zealand. Aust. Plant Pathol. 48, 75-84. doi: 10.1007/s13313-018-0565-9

Thambugala, K. M., Daranagama, D. A., Camporesi, E., Singtripop, C., Liu, Z. Y., and Hyde, K. D. (2014). Multi-locus phylogeny reveals the sexual state of Tiarosporella in Botryosphaeriaceae. Cryptogamie Mycologie 35, 359-368. doi: 10.7872/crym.v35.iss4.2014.359

Theissen, F., and Sydow, H. (1918). Vorentwurfe zu den Pseudosphaeriales. Ann. Mycol. 16, 1-34.

Travadon, R., Rolshausen, P. E., Gubler, W. D., Cadle-Davidson, L., and Baumgartner, K. (2013). Susceptibility of cultivated and wild Vitis spp. to wood infection by fungal trunk pathogens. Plant Dis. 97, 1529-1536. doi: 10.1094/ pdis-05-13-0525-re 
Treangen, T. J., and Salzberg, S. L. (2012). Repetitive DNA and next-generation sequencing: computational challenges and solutions. Nat. Rev. Genet. 13, 36-46. doi: $10.1038 / \operatorname{nrg} 3117$

Urbez-Torres, J. R. (2011). The status of Botryosphaeriaceae species infecting grapevines. Phytopathologia Mediterranea 50, S5-S45.

Úrbez-Torres, J. R., and Gubler, W. D. (2009). Pathogenicity of Botryosphaeriaceae species isolated from grapevine cankers in California. Plant Dis. 93, 584-592. doi: 10.1094/pdis-93-6-0584

Úrbez-Torres, J. R., Leavitt, G. M., Guerrero, J. C., Guevara, J., and Gubler, W. D. (2008). Identification and pathogenicity of Lasiodiplodia theobromae and Diplodia seriata, the causal agents of bot canker disease of grapevines in Mexico. Plant Dis. 92, 519-529. doi: 10.1094/pdis-92-4-0519

Úrbez-Torres, J. R., Peduto, F., Vossen, P. M., Krueger, W. H., and Gubler, W. D. (2013). Olive twig and branch dieback: etiology, incidence, and distribution in California. Plant Dis. 97, 231-244. doi: 10.1094/pdis-04-12-0390-re

Valente, I. D. L., Confortin, T. C., Luft, L., Todero, I., Quadros, G. P., Tonato, D., et al. (2020). Effects of ultrasound on submerged fermentation for producing antioxidant metabolites from Botryosphaeria dothidea. Br. J. Chem. Eng. 37, 475-484. doi: 10.1007/s43153-020-00044-8

Valette, N., Perrot, T., Sormani, R., Gelhaye, E., and Morel-Rouhier, M. (2017). Antifungal activities of wood extractives. Fungal Biol. Rev. 31, 113-123. doi: 10.1016/j.fbr.2017.01.002

Van Dongen, S. M. (2000). Graph Clustering by Flow Simulation. Doctoral dissertation, Netherlands, University of Utrecht.

Wang, B., Liang, X., Gleason, M. L., Zhang, R., and Sun, G. (2018). Comparative genomics of Botryosphaeria dothidea and B. kuwatsukai, causal agents of apple ring rot, reveals both species expansion of pathogenicity-related genes and variations in virulence gene content during speciation. IMA Fungus 9, 243-257. doi: 10.5598/imafungus.2018.09.02.02

Wang, M., Sun, X., Yu, D., Xu, J., Chung, K., and Li, H. (2016). Genomic and transcriptomic analyses of the tangerine pathotype of Alternaria alternata in response to oxidative stress. Sci. Rep. 6:32437.

Wang, Y., Zhang, W., Liu, B., Luan, B., and Wang, P. (2010). Research on resistance and geographical distribution of Botryosphaeria dothidea from apple to Tebuconazole in Shandong province. J. Fruit Sci. 27, 961-964.

Wapinski, I., Pfeffer, A., Friedman, N., and Regev, A. (2007). Natural history and evolutionary principles of gene duplication in fungi. Nature 449, 54-61. doi: 10.1038 /nature06107

White, T. J., Bruns, T., Lee, S. J. W. T., and Taylor, J. (1990). Amplification and direct sequencing of fungal ribosomal RNA genes for phylogenetics. PCR protocols: A Guide to Methods and Applications 18, 315-322. doi: 10.1016/b9780-12-372180-8.50042-1
Xiao, J., Zhang, Q., Gao, Y. Q., Tang, J. J., Zhang, A. L., and Gao, J. M. (2014). Secondary metabolites from the endophytic Botryosphaeria dothidea of Melia azedarach and their antifungal, antibacterial, antioxidant, and cytotoxic activities. J. Agric. Food Chem. 62, 3584-3590. doi: 10.1021/jf50 $0054 \mathrm{f}$

Yan, J. Y., Zhao, W. S., Chen, Z., Xing, Q. K., Zhang, W., Chethana, K. T., et al. (2018). Comparative genome and transcriptome analyses reveal adaptations to opportunistic infections in woody plant degrading pathogens of Botryosphaeriaceae. DNA Res. 25, 87-102. doi: 10.1093/dnares/ds $\mathrm{x} 040$

Zámocký, M., and Obinger, C. (2010). "Molecular phylogeny of heme peroxidases," in Biocatalysis Based on Heme Peroxidases, eds E. Torres and M. Ayala (Berlin; Heidelberg: Springer), 7-35. doi: 10.1007/978-3-642-12627-7_2

Zámocký, M., Gasselhuber, B., Furtmüller, P. G., and Obinger, C. (2014). Turning points in the evolution of peroxidase-catalase superfamily: molecular phylogeny of hybrid heme peroxidases. Cell. Mol. Life Sci. 71, 4681-4696. doi: 10.1007/s00018-014-1643-y

Zamocky, M., Ludwig, R., Peterbauer, C., Hallberg, B. M., Divne, C., Nicholls, P., et al. (2006). Cellobiose dehydrogenase-a flavocytochrome from wooddegrading, phytopathogenic and saprotropic fungi. Curr. Protein Pept. Sci 7 , 255-280. doi: 10.2174/138920306777452367

Zhang, H., Yohe, T., Huang, L., Entwistle, S., Wu, P., Yang, Z., et al. (2018). dbCAN2: a meta server for automated carbohydrate-active enzyme annotation. Nucleic Acids Res. 46, W95-W101.

Zhang, J. (2003). Evolution by gene duplication: an update. Trends Ecol. Evol. 18, 292-298. doi: 10.1016/s0169-5347(03)00033-8

Zhao, Z., Liu, H., Wang, C., and Xu, J. R. (2013). Comparative analysis of fungal genomes reveals different plant cell wall degrading capacity in fungi. BMC Genomics 14:274. doi: 10.1186/1471-2164-14-274

Conflict of Interest: The authors declare that the research was conducted in the absence of any commercial or financial relationships that could be construed as a potential conflict of interest.

Copyright (C) 2021 Garcia, Lawrence, Morales-Cruz, Travadon, Minio, HernandezMartinez, Rolshausen, Baumgartner and Cantu. This is an open-access article distributed under the terms of the Creative Commons Attribution License (CC BY). The use, distribution or reproduction in other forums is permitted, provided the original author(s) and the copyright owner(s) are credited and that the original publication in this journal is cited, in accordance with accepted academic practice. No use, distribution or reproduction is permitted which does not comply with these terms. 